\title{
KARAKTERISTIK BATUAN PEMBAWA KALIUM DI KECAMATAN CLUWAK, KABUPATEN PATI, PROVINSI JAWA TENGAH
}

\section{CHARACTERISTICS OF POTASSIUM-BEARING ROCK IN CLUWAK SUB-DISTRICT, PATI REGENCY, CENTRAL JAVA PROVINCE}

\author{
Herry Rodiana Eddy dan Irwan Muksin \\ Pusat Sumber Daya Mineral, Batubara dan Panas Bumi \\ herry.eddy@esdm.go.id
}

\begin{abstract}
ABSTRAK
Peningkatan kebutuhan kalium untuk industri pupuk dalam negeri dapat terpenuhi dengan melakukan eksplorasi batuan pembawa kalium secara terus menerus sehingga ditemukan daerah potensi baru di Indonesia. Batuan pembawa kalium di Kecamatan Cluwak, Kabupaten Pati, Provinsi Jawa Tengah merupakan salah satu daerah prospek dari beberapa daerah di Kabupaten Jepara, Kabupaten Pati dan Kabupaten Kudus, karena batas toleransi minimal yang dipersyaratkan sebagai pupuk NPK padat mempunyai kandungan kalium sebagai $\mathrm{K}_{2} \mathrm{O}$ minimal $8 \%$.
\end{abstract}

Metode yang digunakan berupa kegiatan pemetaan geologi, pengamatan lapangan pada formasi batuan yang terindikasi keterdapatan batuan pembawa kalium, pengeboran sebanyak tiga titik bor, analisis kimia major elements, berat jenis, petrografi batuan, dan raman spectrocopy terhadap conto permukaan dan bawah permukaan.

Stratigrafi daerah Kecamatan Cluwak tersusun atas Satuan Batuan Gunung Muria, yang terdiri dari lava, breksi dan tuf, yang melampar hampir di keseluruhan daerah penyelidikan, dan Satuan Batugamping yang merupakan batuan pembawa kalium yang terdiri dari lava, breksi dan tuf ini tersingkap di bagian utara. Lava di daerah ini sebagian telah mengalami pelapukan dan memperlihatkan pelapukan mengulit bawang.

Batuan pembawa kalium dapat dibagi ke dalam tiga blok sebaran, yaitu Blok Karangsari, Blok Sentul, dan Blok Medani. Jenis batuannya berupa batuan alkali, dan beberapa conto batuan yang masuk jenis batuan sub-alkali pada batuan basal. Selain itu menunjukkan adanya jenis batuan seri alkalin yang mengandung silika rendah dan alkalin yang tinggi, terbagi menjadi absarokite dan shoshonite, juga termasuk pada golongan Seri Kalium (Potassic Series) sampai Seri Kalium Tinggi (High-K-Series).

Berdasarkan parameter tanah $\mathrm{K}_{2} \mathrm{O}, \mathrm{HCl} 25 \%$ menghasilkan lima kategori dengan prosentase $9,1 \%$ termasuk kriteria sangat rendah, $13,6 \%$ rendah, $8,2 \%$ sedang, $16,4 \%$ tinggi dan $51,8 \%$ sangat tinggi. Sedangkan dengan parameter tanah Asam sitrat $2 \%$ Bray didapatkan hasil $100 \%$ termasuk kriteria sangat tinggi.

Kata kunci: batuan pembawa kalium, kalium oksida, leusit, Cluwak, Pati

\section{ABSTRACT}

Increasing potassium needs for the domestic fertilizer industry can be fulfilled by carrying out exploration of potassium-carrying rocks continuously so that new potential areas are found in Indonesia. Cluwak Sub-district, Pati Regency, Central Java Province is a prospect area to find Potassium-bearing rock from several observation regions, including Jepara Regency, Pati Regency and Kudus Regency. The Potassium-bearing rock found in Cluwak Sub-district meets 


\section{MAKALAH ILMIAH}

the requirement of minimum tolerance limit solid NPK fertilizer which has a minimum potassium content of $\mathrm{K}_{2} \mathrm{O}$ of $8 \%$.

The methods used include geological mapping activities, field observations on rock formations which indicated the presence of potassium-bearing rocks, drilling of three drill points, chemical analysis of major elements, specific gravity, petrographic rocks, and raman spectrocopy for surface and subsurface samples.

The Stratigraphy of Cluwak Sub-district is composed of the Muria Mountain Rock Unit, which consist of lava, breccia and tuff extend almost in the entire investigation area, and the Limestone Unit which revealed in the northern area of investigation. Potassium-bearing rock in Cluwak Sub-district, Pati Regency consists of lava, breccia and tuff. A spheroidal weathering occurred in some lava. In Cluwak Sub-district, Pati Regency, potassium-bearing rocks can be divided into three distribution blocks, namely Karangsari Block, Sentul Block, and Medani Block. The type of rock found is an alkaline rock, and some other rock samples are sub-alkali rock types in basalt rock. In addition, it also shows the types of alkaline serie rocks containing low silica and high alkalinity, which are divided into absarokite and shoshonite, which also included in the Potassium Series group to the High Potassium Series.

Based on $\mathrm{K}_{2} \mathrm{O}$ soil parameters using $25 \% \mathrm{HCl}$ it categorizes into five categories; very low $(9.1 \%)$, low (13.6\%), moderate (8.2\%), high (16.4\%) and very high (51.8\%). Whereas with soil parameters using Citric Acid 2\% Bray obtained 100\% results, which categorizes as very high criteria.

Keywords: potassium of bearing rock, potassium oxide, leucite, Cluwak, Pati

\section{PENDAHULUAN}

Indonesia merupakan negara yang mengandalkan sektor agraris sebagai salah satu penggerak perekonomian. Luasnya lahan dan kesuburan tanah yang dimiliki tentu menjadi anugerah tersendiri. Besarnya peranan sektor agraris di Indonesia tidak terlepas dari industri pupuk. Seiring dengan meningkatnya kebutuhan, hasil sektor pertanian, kebutuhan pupuk pun semakin meningkat. Pemerintah memutuskan untuk mengambil alih pengelolaan industri pupuk dikarenakan industri pupuk merupakan sektor strategis guna menyokong ketahanan pangan nasional (Lasindrang dan Fauzi, 2018).

Berbagai kebijakan dalam pengembangan industri pupuk nasional telah diberlakukan pemerintah. Terkait dengan kebijakan strategis pengembangan industri pupuk nasional, pemerintah menerbitkan Instruksi Presiden RI Nomor 2 Tahun 2010 tentang Revitalisasi Industri Pupuk Nasional, dan Peraturan Menteri Perindustrian Nomor 141/2010 tentang Rencana Induk
Pengembangan Industri Pupuk Majemuk/NPK. Dalam Peraturan ini disajikan rencana nasional mengenai sasaran, arah, strategi, dan kebijakan

pengembangan industri pupuk majemuk/NPK dalam mendukung program ketahanan pangan. Pupuk majemuk yang dimaksud merupakan pupuk yang mengandung lebih dari satu jenis unsur hara makro, seperti nitrogen, fosfat, dan kalium (Suryana, dkk., 2016).

Tema dalam Rencana Kerja Pemerintah Tahun 2019 ini yaitu Pemerataan Pembangunan untuk Pertumbuhan Berkualitas. Pupuk bersubsidi untuk sektor pertanian sebagaimana diamanatkan Peraturan Presiden Nomor 15 Tahun 2011 harus memperhatikan prinsip 6 tepat, yaitu tepat jenis, jumlah, waktu, tempat, harga, dan mutu (Anonim, 2018). Tujuan subsidi pupuk yang paling penting yaitu ketersediaan pupuk, peningkatan produksi pangan, peningkatan pendapatan petani dan penyerapan tenaga kerja. Jenis subsidi pupuk yang menjadi prioritas yaitu pupuk 
anorganik selanjutnya pupuk organik (Hendrawan, dkk., 2011).

PT. Pupuk Kaltim sebagai salah satu produsen pupuk di tanah air mengkhawatirkan adanya serbuan pupuk impor dengan mudah dan murah. Petani akan beralih menggunakan pupuk impor karena harganya terjangkau (murah)

dibanding pupuk produksi dalam negeri. Selain itu pupuk mudah didapat, terutama pupuk dari Tiongkok dan Amerika Serikat.

Pupuk Kalium yang banyak digunakan di Indonesia yaitu kalium klorida $(\mathrm{KCl})$, namun akhir-akhir ini berkembang dengan menggunakan kalium sulfat $\left(\mathrm{K}_{2} \mathrm{SO}_{4}\right)$. Hasil penelitian menunjukkan telah terbukti $\mathrm{K}_{2} \mathrm{SO}_{4}$ mampu memperbaiki kualitas karakteristik beberapa produk sayuran (Gunadi, 2007 dalam Syakir dan Gusmaini, 2012). Kalium merupakan salah satu unsur hara yang terdapat di tanah dan menjadi satu-satunya kation monovalent yang sangat penting bagi tanaman, karena kalium memiliki fungsi sebagai aktivator berbagai enzim yang terdapat di dalam tanaman. Ketersediaan kalium di tanah menyebabkan ketegaran tanaman menjadi lebih terjamin, merangsang pertumbuhan kualitas bulir, mampu mengurangi pengaruh kematangan yang dipercepat oleh fosfor dan dapat mengatasi kekurangan air pada waktu dan tingkat tertentu (Ariawan, dkk, 2016 dalam Khoirunisa, 2017).

Penulisan makalah ini dimaksudkan untuk mengetahui lebih detail kualitas dan sebaran batuan pembawa kalium di Kecamatan Cluwak, Kabupaten Pati, Provinsi Jawa Tengah, meliputi jenis batuan berdasarkan Raman Spectroscopy dan kandungan $\mathrm{SiO}_{2}, \mathrm{~K}_{2} \mathrm{O}$ serta $\mathrm{Na}_{2} \mathrm{O}$ hasil analisis laboratorium terhadap conto permukaan maupun bawah permukaan yang dilakukan pengambilan melalui metode pengeboran, sehingga dapat memberikan informasi karakteristik batuan pembawa kalium guna menunjang kebutuhan industri pupuk di Indonesia.
Penyelidikan batuan pembawa kalium di Wilayah Gunung Muria, Jawa Tengah dilakukan di Kabupaten Jepara, Kabupaten Pati dan Kabupaten Kudus. Di Kabupaten Jepara kualitas batuan pembawa kalium mempunyai kandungan $\mathrm{K}_{2} \mathrm{O}$ antara $0,89 \%$ s.d. $7,22 \%$, terdapat pada batuan sanidine, quartz dan monmorilonite (Muksin, 2011 dan Muksin, 2015). Di Kabupaten Kudus kualitas batuan pembawa kalium mempunyai kandungan $\mathrm{K}_{2} \mathrm{O}$ antara $1,08 \%$ s.d. $6,06 \%$, terdapat pada batuan anorthoclase, labradorite, diopside, andesine, analcime, siderite, calsium dan apatite (Muksin, 2017). Di Kabupaten Pati mempunyai kandungan $\mathrm{K}_{2} \mathrm{O}$ antara $1,92 \%$ s.d. $8,79 \%$, terdapat pada batuan leucite, augite, piroksen, quartz, dan sanidine (Muksin, 2016).

Berdasarkan hasil penyelidikan di tiga kabupaten tersebut, Kabupaten Pati merupakan daerah prospek karena memenuhi batas toleransi minimal yang dipersyaratkan sebagai pupuk NPK padat mempunyai kandungan kalium sebagai $\mathrm{K}_{2} \mathrm{O}$ minimal 8\% (SNI 2803:2010). Sehubungan dengan hal di atas, pada Tahun 2018 daerah di Kabupaten Pati ditindaklanjuti dengan metoda pengeboran khususnya untuk Blok Medani, Blok Sentul dan Blok Karangsari (pengembangan dari Blok Mojo sebelumnya), dengan dasar ketiga blok tersebut mempunyai kandungan $\mathrm{K}_{2} \mathrm{O}$ yang relatif lebih tinggi dibandingkan dengan blok lainnya. Ketiga blok di Kabupaten Pati yang dilakukan penyelidikan lanjutan secara administrasi termasuk Kecamatan Cluwak.

\section{METODOLOGI}

Metode yang digunakan antara lain kegiatan pemetaan geologi dan pengamatan lapangan di wilayah Kecamatan Cluwak melalui lintasan jalan dan sungai. Pemilihan lintasan berdasarkan hasil peta geologi pada formasi batuan yang terindikasi keterdapatan batuan pembawa kalium. Pengamatan litologi di daerah penyelidikan dilakukan pada lembah dan perbukitan 


\section{MAKALAH ILMIAH}

yang batuannya tersingkap. Pengambilan conto batuan dilakukan dengan cara grab sampling (Gambar 1). Dilakukan juga kegiatan pengeboran sebanyak tiga titik bor pada daerah yang dianggap mempunyai kualitas yang baik (Gambar 2). Untuk dapat mengetahui kualitas batuan pembawa kalium, maka dilakukan metode analisis kimia major elements, berat jenis, petrografi batuan, dan raman spectrocopy terhadap conto permukaan dan bawah permukaan. Selanjutnya dilakukan pengolahan data lapangan dan data hasil analisis laboratorium untuk mengetahui karakteristik batuan pembawa kalium pada ketiga blok tersebut.

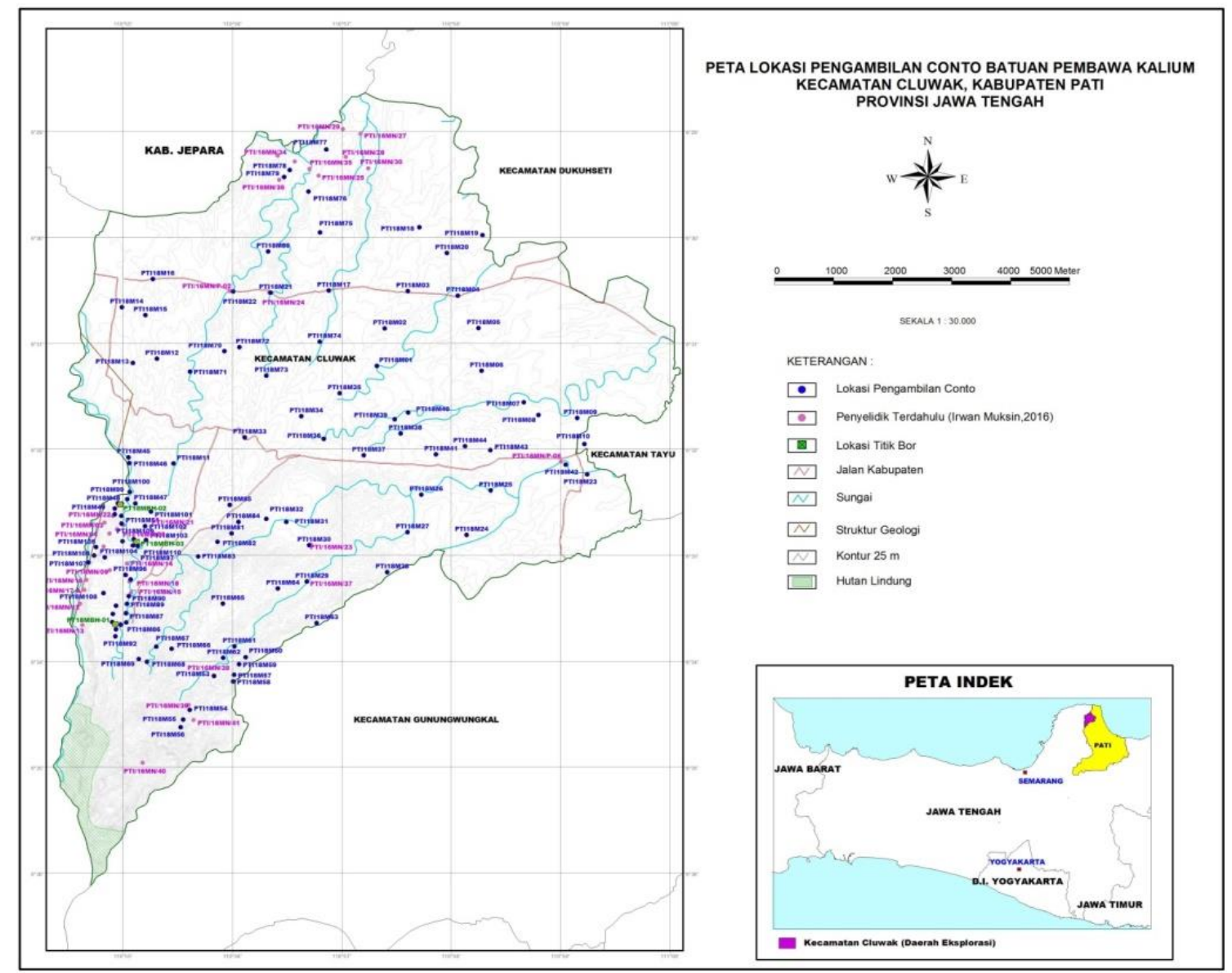

Gambar 1. Peta lokasi pengambilan conto dan lokasi pengeboran di Kecamatan Cluwak, Kabupaten Pati

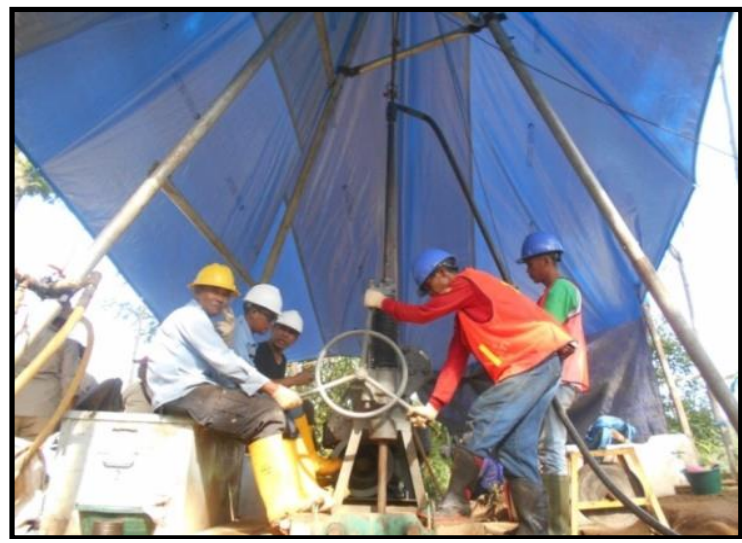

Gambar 2. Kegiatan pengeboran uji geologi menggunakan mesin jenis Sander SD-3C 


\section{HASIL DAN PEMBAHASAN}

Berdasarkan peta geologi yang diterbitkan oleh Pusat Penelitian dan Pengembangan Geologi, Bandung, Lembar Kudus (Suwarti dan Wikarno, 1992) dan Lembar Rembang (Kadar dan Sudijono, 1993), geologi Kabupaten Pati disusun oleh Formasi Tawun (Tmt), Formasi Ngrayong (Tmn), Formasi Bulu (Tmb), Formasi Wonocolo (Tmw), Formasi Ledok (Tml), Formasi Mundu (Tmpm), Formasi Patiayam (Tpp), Anggota Selorejo (QTps), Formasi Lidah
(QTpl), Lava Muria (Qvlm), Batuan Gunungapi Muria (Qvm), dan Aluvium (Qa). Peta geologi Kabupaten Pati dapat dilihat pada Gambar 3. Formasi batuan yang terdapat di Kecamatan Cluwak terdiri dari Lava Muria (Qvim), merupakan lava basal atau andesit, leusit, tefrit, leusitit, trakhit dan sienit. Serta Batuan Gunungapi Muria (Qvm) tersusun dari hasil kegiatan Gunung Muria yang berupa tuf, lahar dan tuf pasiran. Lahar tersusun oleh fragmen leusit, basal, andesit, batugamping dan batuan metamorf.

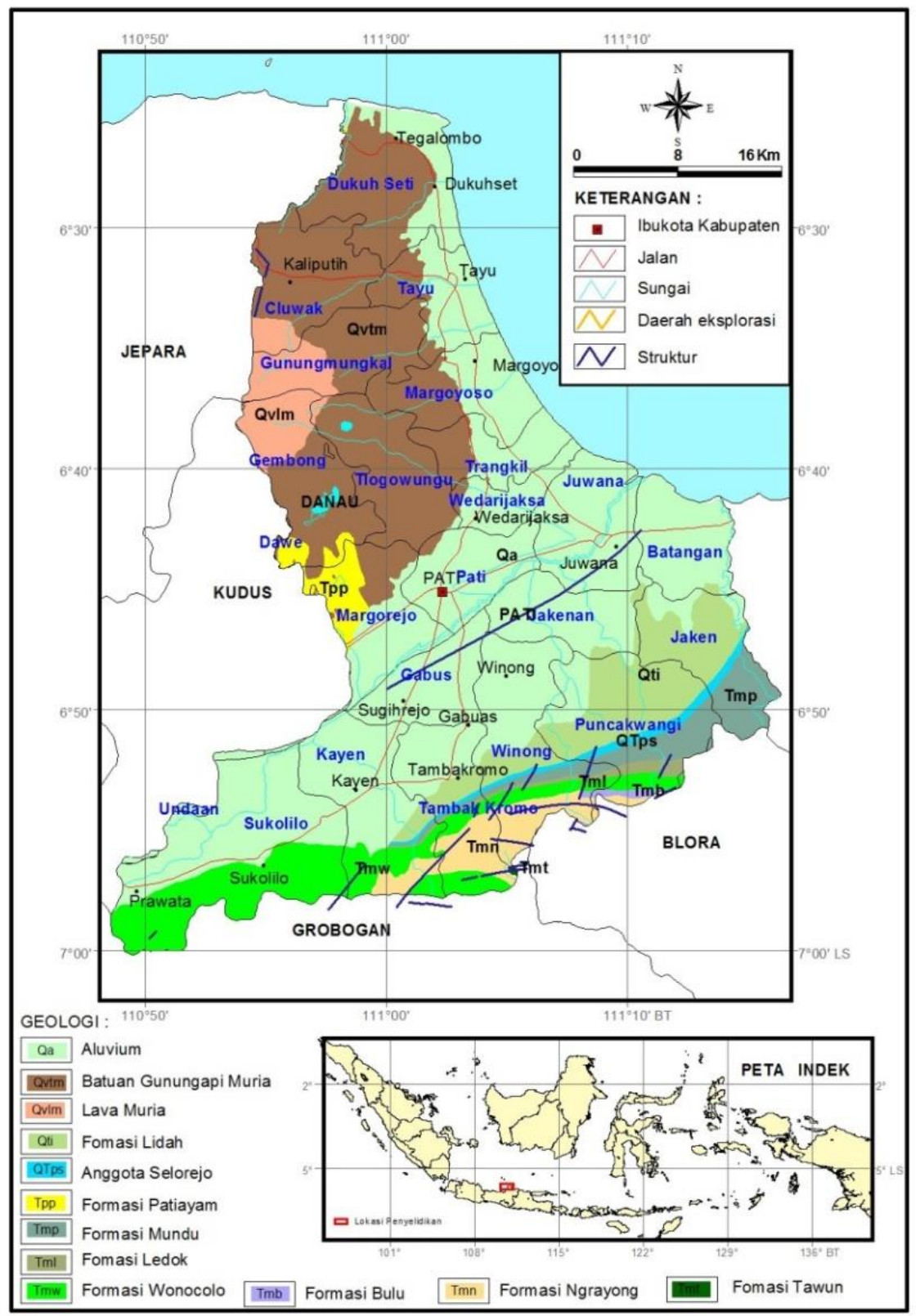

Gambar 3. Peta Geologi Kabupaten Pati, Jawa Tengah

(modifikasi: Suwarti dan Wikarno, 1992 serta Kadar dan Sudijono, 1993) 
Struktur geologi yang terdapat di daerah ini adalah sesar, kelurusan dan kubah. Sesar normal dengan arah timurlaut hingga baratdaya. Kelurusan dijumpai baik pada batuan tua maupun muda. Kelurusan yang dijumpai di bagian utara Gunung Muria dan di Gunung Muria sendiri menunjukkan berbagai arah yang tak teratur. Struktur kubah dijumpai di daerah Patiayam, merupakan suatu diapir. Kegiatan gunungapi Kuarter yang bersumber pada Gunung Genuk dan Gunung Muria menghasilkan batuan Gunungapi Genuk dan Muria, serta diikuti dengan terjadinya retas-retas batuan beku. Retas-retas basal mengandung leusit, yang setempat berasosiasi dengan batugamping dan terjadi sewaktu kegiatan Gunungapi Muria masih berlangsung. Magma basal yang menerobos batugamping dan menyeret bongkahan batugamping kepermukaan, sempat berasimilasi dan menghasilkan retas sosonit dengan xenolite batugamping. Singkapannya dijumpai di daerah Semliro, sebelah selatan Gunung Muria.

Conto permukaan dan bawah permukaan dianalisis dengan beberapa metode analisis laboratorium, seperti analisis kimia major element ditambah dengan berat jenis (BJ), analisis petrografi, analisis raman spectrocopy dan analisis kimia tanah. Jumlah conto yang dianalisis berikut parameter analisis laboratorium seperti terlihat pada Tabel 1.

Berdasarkan ciri-ciri litologi yang teramati di lapangan dan dari pola morfologi, terdapat Satuan Batuan Gunung Muria dan Satuan Batugamping, dengan deskripsi lapangan dari masing-masing satuan batuan tersebut yaitu:

Satuan Batuan Gunung Muria, terdiri dari lava, breksi dan tuf, satuan ini melampar hampir di keseluruhan daerah penyelidikan, lava, berwarna abu kehitaman, keras, struktur mengulit bawang, setempat dijumpai mineral leusit berwarna putih (Gambar 4.). Breksi gunungapi, berwarna abu-abu tua, kompak dengan komponen basal, basal leusit dan andesit, serta masa dasar batupasir tufaan. Setempat komponen breksi mengalami pelapukan mengulit bawang (Gambar 5.). Tuf berwarna kecoklatan, terdapat bintik-bintik putih, berlapis kurang baik, berbutir halus sampai kasar, sebagian telah mengalami pelapukan dan rapuh (Gambar 6.).

Satuan Batugamping, satuan ini tersingkap di bagian utara daerah penyelidikan, batugamping terumbu berwarna krem, berbutir halus, keras, masih terdapat cangkang fosil, bereaksi dengan $\mathrm{HCl}$.

Tabel 1. Jenis dan jumlah conto analisis laboratorium

\begin{tabular}{cllc}
\hline No & \multicolumn{1}{c}{ Jenis Conto } & \multicolumn{1}{c}{ Jenis Analisis } & Jumlah \\
\hline 1 & Batuan (Singkapan) & Kimia (major element dan BJ) & 113 \\
\hline 2 & Batuan (Singkapan) & Petrografi & 4 \\
\hline 3 & Batuan (Singkapan) & Raman Spectroscopy & 6 \\
\hline 4 & Batuan (Singkapan) & Kimia Tanah & 70 \\
\hline 5 & Inti Bor & Kimia (major element dan BJ) & 68 \\
\hline 6 & Inti Bor & Petrografi & 6 \\
\hline 7 & Inti Bor & Raman Spectroscopy & 9 \\
\hline 8 & Inti Bor & Kimia Tanah & 40 \\
\hline & & Total & 316 \\
\hline
\end{tabular}




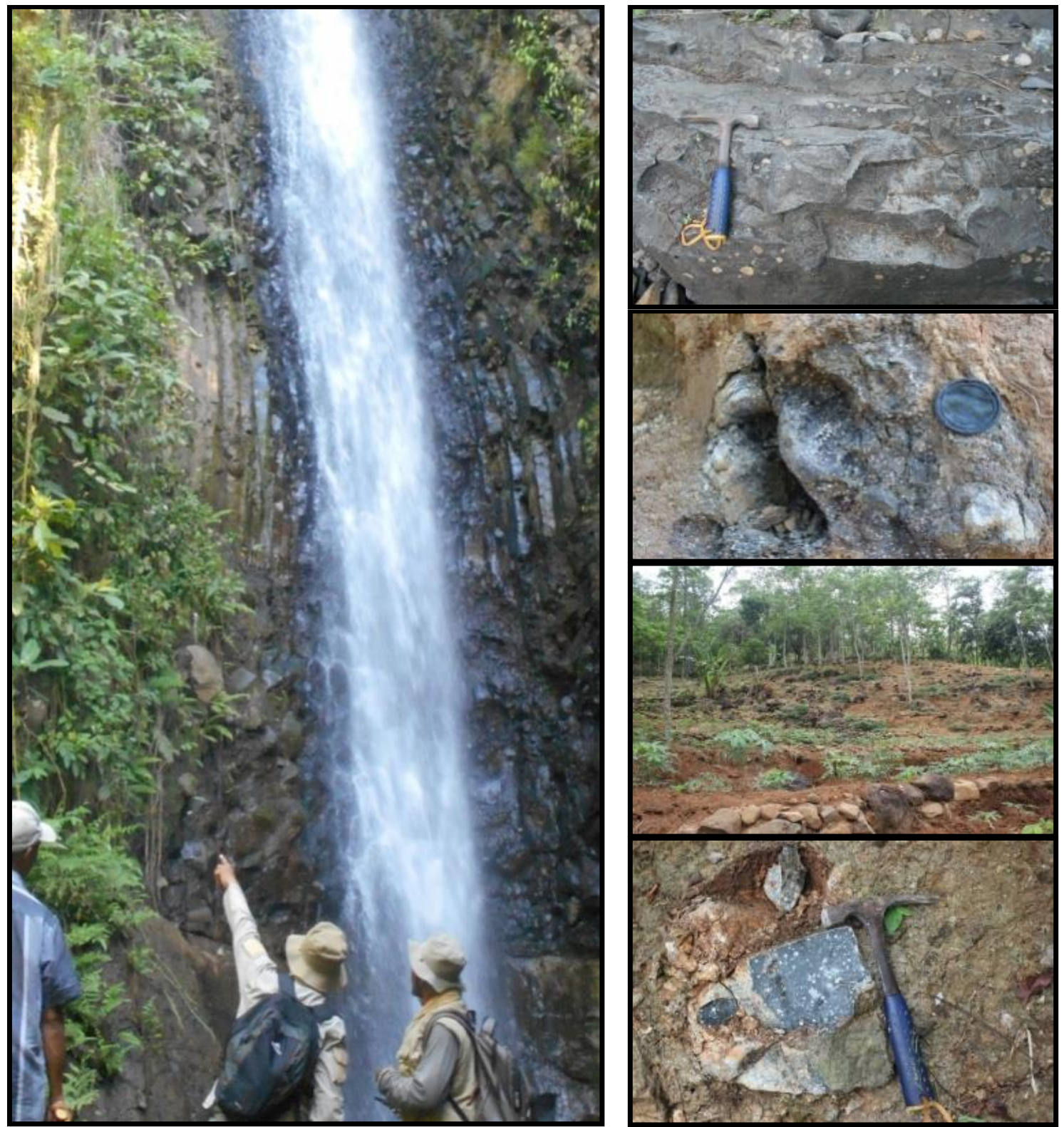

Gambar 4. Singkapan lava di Kecamatan Cluwak, Pati


Gambar 5. Singkapan breksi di Kecamatan Cluwak, Pati 


\section{MAKALAH ILMIAH}

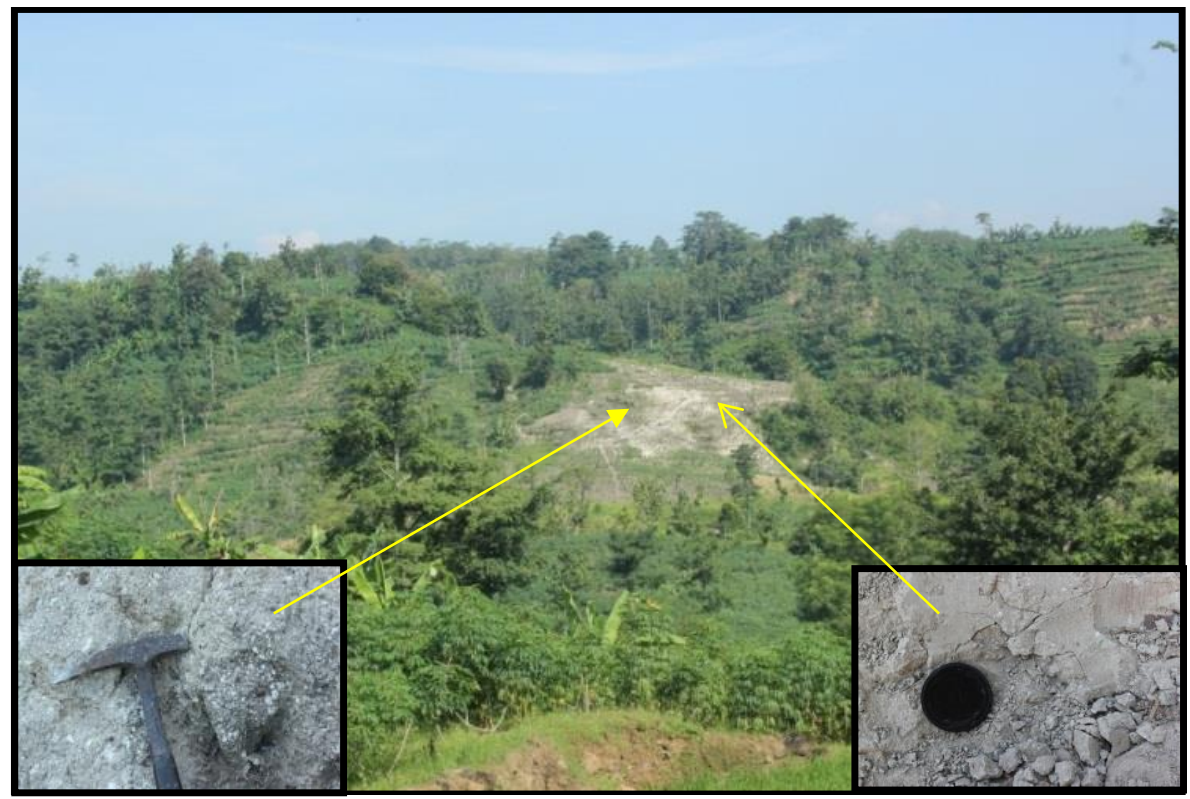

Gambar 6. Singkapan tuf di daerah Mojo, Kecamatan Cluwak, Pati

Berdasarkan hasil penyelidikan sebelumnya, Blok Medani mempunyai kandungan $\mathrm{K}_{2} \mathrm{O}$ berkisar antara $1,92 \%$ s.d. $8,77 \%$ yang relatif lebih tinggi dibandingkan dengan blok lainnya. Pada Blok Medani ini dilakukan pengeboran sebanyak tiga titik bor dengan kedalaman $30 \mathrm{~m}$ dan $35 \mathrm{~m}$. Pada titik bor pertama (BH 01), kedalaman $3,00 \mathrm{~m}$ sampai $17,90 \mathrm{~m}$ didominasi basal berwarna abu-abu terang dan masif. Kemudian pada kedalaman 17,90 m sampai $30,00 \mathrm{~m}$ terdiri atas breksi laharik warna abu-abu kecoklatan, semi lapuk, fragmen batuan beku warna abu-abu, setempat dijumpai batuan leusitik diantaranya pada kedalaman 28,15 m seperti terlihat pada Gambar 7. Di titik bor kedua ( $\mathrm{BH} 02$ ), kedalaman 7,00 m sampai $35,00 \mathrm{~m}$ terdiri atas breksi laharik warna abu-abu kecoklatan, semi lapuk, fragmen batuan beku warna abu-abu, setempat dijumpai leusit. Sedangkan titik bor ketiga (BH 03), pada kedalaman $6,00 \mathrm{~m}$ sampai $35,00 \mathrm{~m}$ terdiri atas breksi laharik warna abu-abu kecoklatan, semi lapuk, fragmen batuan beku warna abu-abu, setempat dijumpai leusit. Breksi laharik kedalaman 30 sampai $35 \mathrm{~m}$ seperti terlihat pada Gambar 8.

Hasil rekonstruksi pada ketiga titik bor, tidak dapat dikorelasikan secara horizontal, dikarenakan ketiga titik bor tersebut berada pada elevasi ketinggian yang berbeda. Lokasi titik bor berdasarkan elevasi beserta kadar $\mathrm{K}_{2} \mathrm{O}$ di atas $4 \%$ pada masing-masing lapisan batuan seperti terlihat pada Gambar 9.

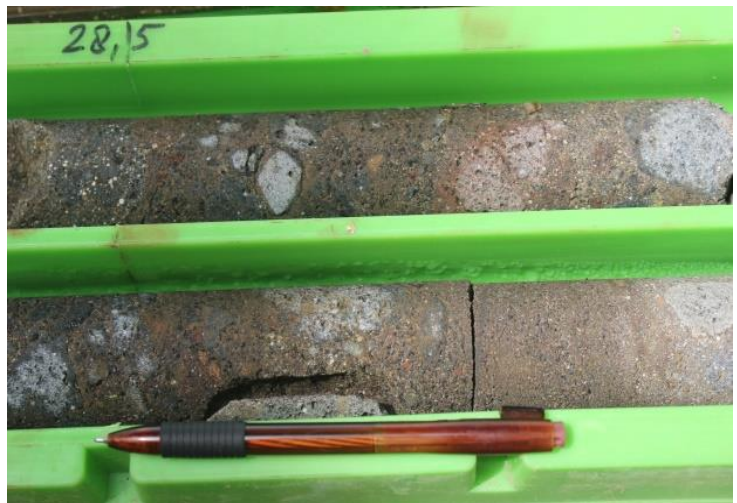

Gambar 7. Inti bor breksi laharik di $\mathrm{BH} 01$ pada kedalaman 28,15 m

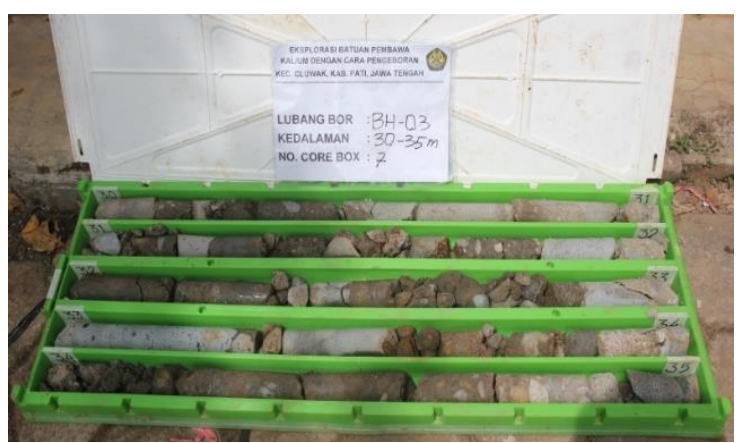

Gambar 8. Inti bor Breksi laharik kedalaman 30 m s.d. $35 \mathrm{~m}$ pada inti bor di $\mathrm{BH} 03$ 


\section{MAKALAH ILMIAH}

Skala Horisontal : 1 : 6000

Skala Vertikal : $1: 750$



\section{BH 01}
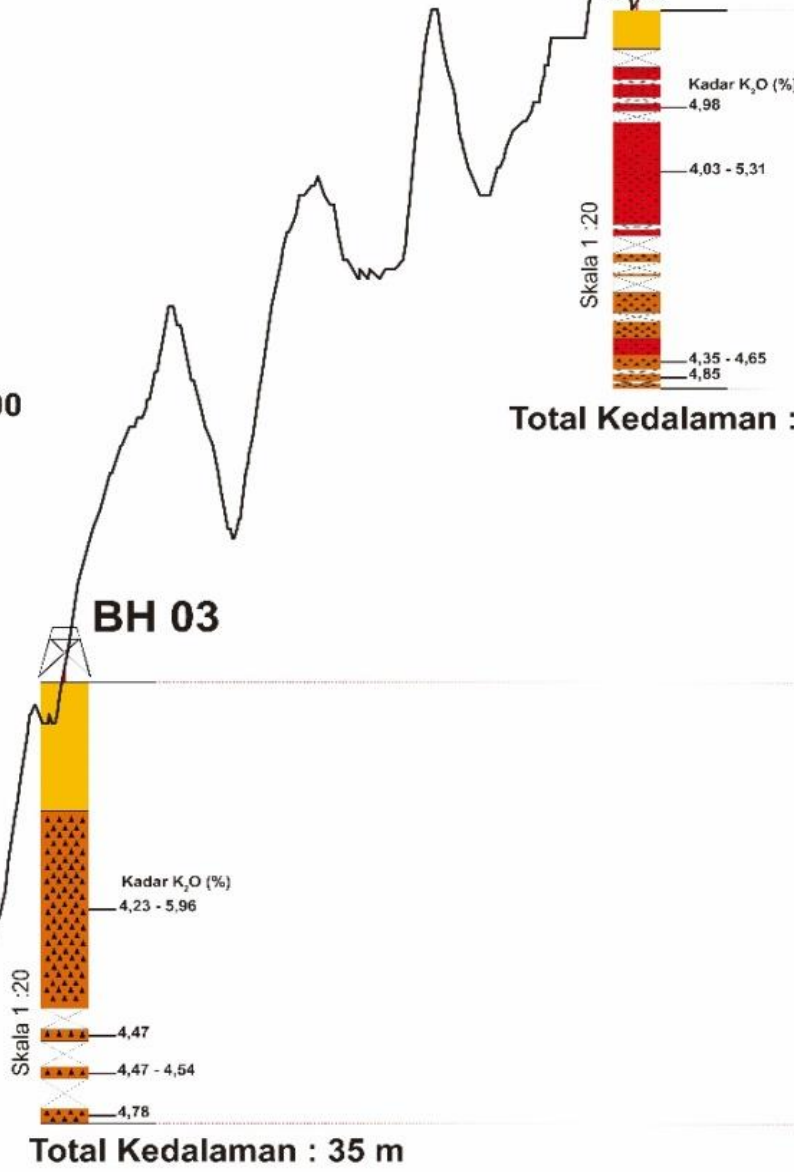

Elevasi
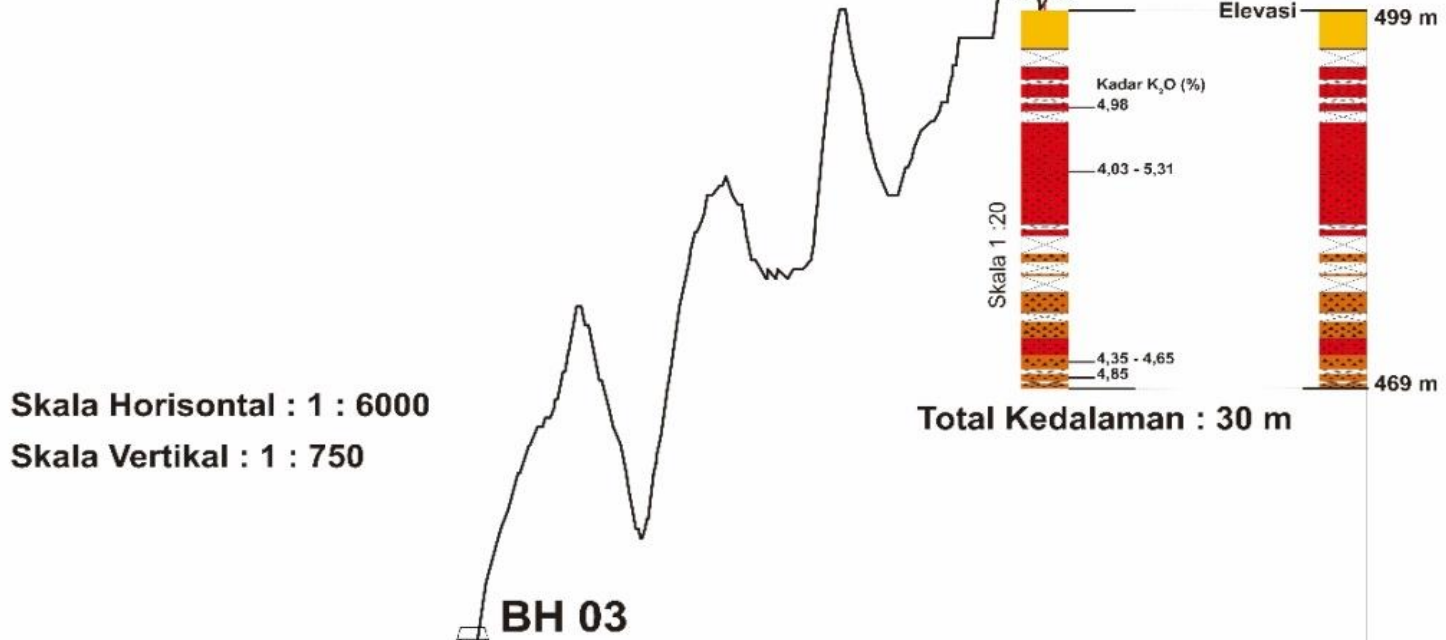
$402 \mathrm{~m}$ 本

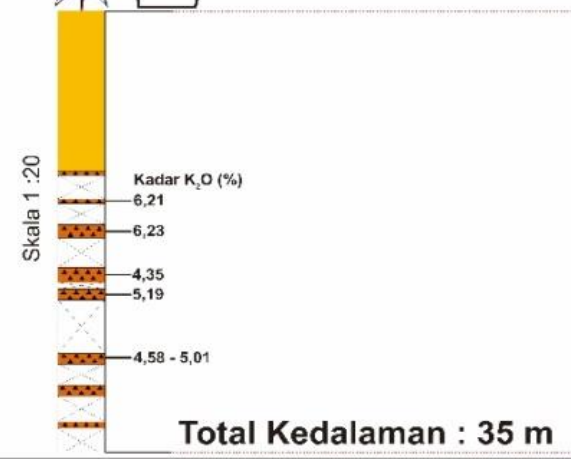

Gambar 9. Lokasi titik bor berdasarkan elevasi di Blok Medani, Kecamatan Cluwak, Kabupaten Pati, Jawa Tengah 


\section{MAKALAH ILMIAH}

Berdasarkan pengamatan di lapangan dan inti bor, susunan batuan pembawa kalium di Kecamatan Cluwak terdiri dari; bagian atas lava dan bagian bawah breksi. Batuan lava sebagian telah mengalami pelapukan mengulit bawang sedangkan potensinya ditemukan di Blok Karangsari, Blok Sentul, dan Blok Medani.

\section{Blok Karangsari}

Blok Karangsari memiliki luas sebaran $3,091 \mathrm{Ha}$, berat jenis rata-rata 2,83 diperoleh sumber daya tertunjuk sebesar 8.129.281.000 ton. Hasil analisis kimia major element terhadap 54 conto permukaan, kandungan $\mathrm{K}_{2} \mathrm{O}$ berkisar antara $1,94 \%$ s.d. $6,93 \%$. Kandungan $\mathrm{K}_{2} \mathrm{O}$ pada batuan lava berkisar antara $1,94 \%$ s.d $6,93 \%$, dengan rata-rata $5,17 \%$, sedangkan pada batuan breksi laharik berkisar antara $2,21 \%$ s.d $5,85 \%$, dengan rata-rata $4,23 \%$. Hasil analisis petrografi di Blok Karangsari disusun oleh mineral leusit dan plagioklas, di dalam massa dasar yang disusun oleh mineral leusit, mikrolit plagioklas, dan opak. Dengan komposisi mineral leusit (63\%), plagioklas (22\%), piroksen $(7 \%)$, opak $(5 \%)$, dan klorit $(3 \%)$, tekstur porfiritik, berukuran butir halus hingga $1,58 \mathrm{~mm}$, bentuk kristal euhedral hingga anhedral, terdapat urat halus yang terisi oleh klorit (Gambar 10). Hasil analisis raman spectroscopy mengandung mineral leusit $(72,23 \%)$, anorthoklas $(90,82 \%)$, augit $(62,19 \%)$, labradorit, hydroxylapatit, diopsid, dan andesin (Gambar 11).

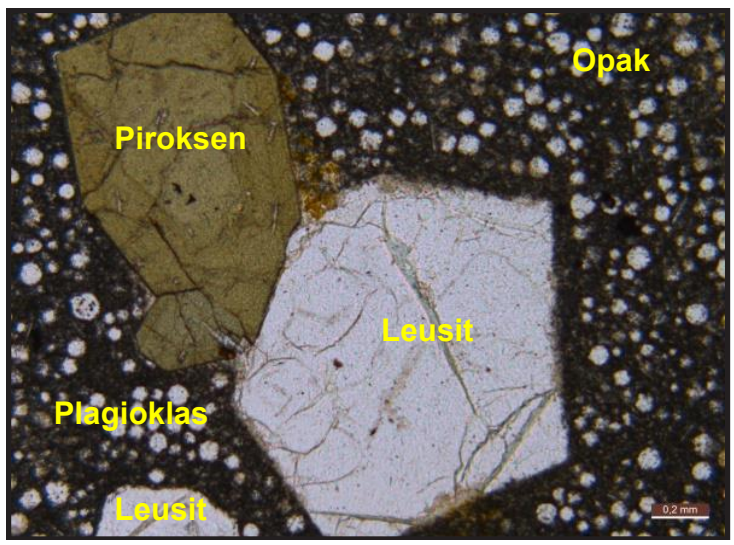

Gambar 10. Fotomikrograf sayatan tipis, berupa mineral leusit dan plagioklas
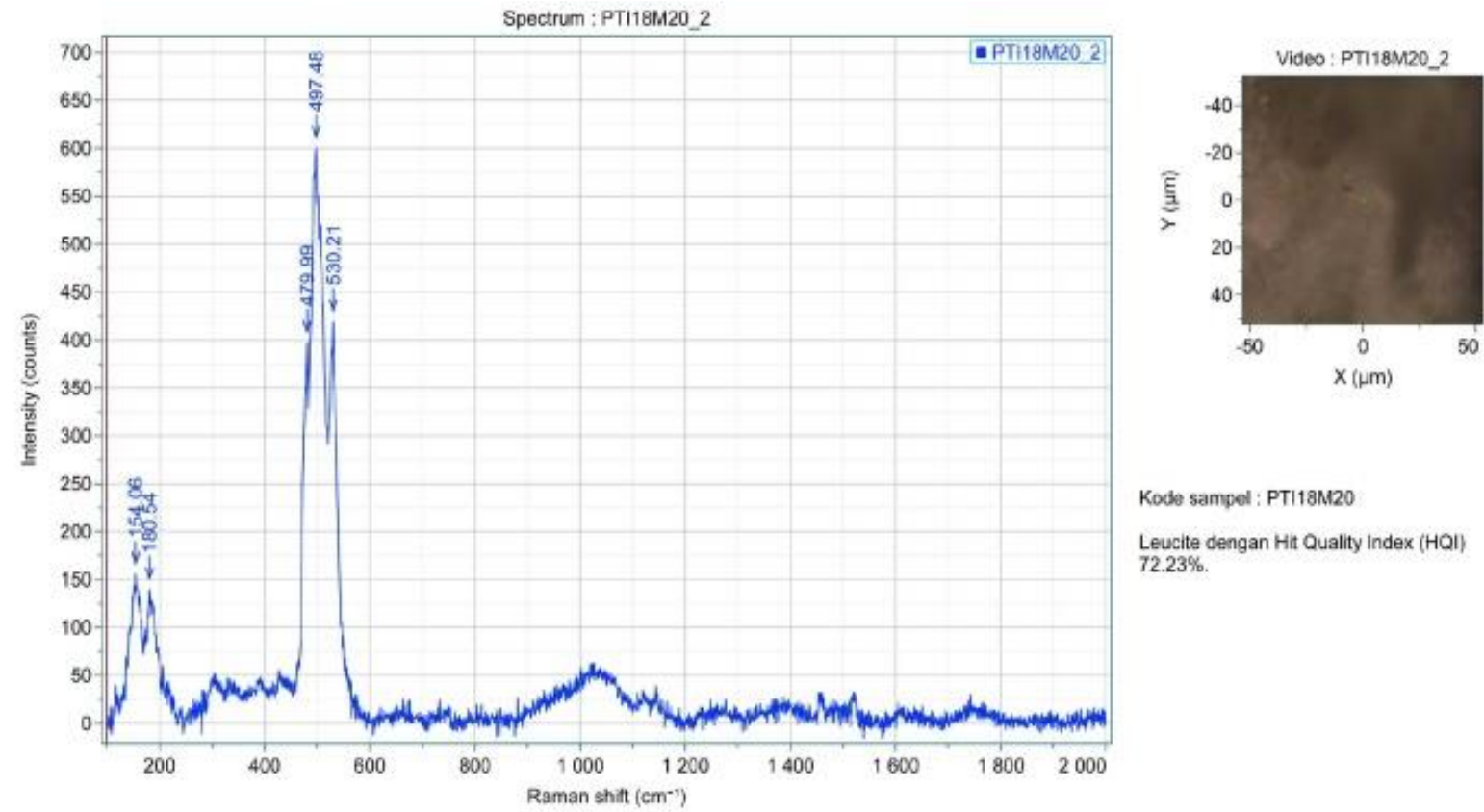

Kode sampel : PTI18M20

Leucite dengan Hit Quality Index (HOl) $72.23 \%$.

\begin{tabular}{|c|c|c|c|c|c|c|c|}
\hline Instrument & XploRA Plus & Acq, time (s) & 2 & Acoumulations & 7 & Laser (nm) & 532 \\
\hline Spectro (cm-") & & Hole $(\mu \mathrm{m})$ & 500 & Sit $(\mu \mathrm{m})$ & 200 & Grating & $2400 \mathrm{gr} / \mathrm{mm}$ \\
\hline Fiter & $100 \%$ & Objective & ×5OLIVD & ICS correction & Oाt & Range $(\mathrm{cm}-1]$ & \\
\hline
\end{tabular}

Gambar 11. Mineral leusit hasil analisis raman spectroscopy 


\section{Blok Sentul}

Blok Sentul memiliki luas sebaran sekitar $1.071 \mathrm{Ha}$, berat jenis rata-rata 2,85 diperoleh sumber daya tertunjuk 4.793.905.000 ton. Hasil analisis kimia major element terhadap 27 conto permukaan mempunyai kandungan $\mathrm{K}_{2} \mathrm{O}$ berkisar $0,55 \%$ s.d. $7,95 \%$. Kandungan $\mathrm{K}_{2} \mathrm{O}$ pada batuan lava berkisar antara $0,55 \%$ s.d $7,99 \%$, dengan rata-rata $4,81 \%$, sedangkan pada batuan breksi berkisar antara $2,41 \%$ s.d. $6,92 \%$, dengan rata-rata $5,10 \%$. Hasil analisis petrografi di Blok Sentul disusun oleh mineral opak dan piroksen, di dalam massa dasar yang disusun oleh mineral mikrogranular piroksen, dan opak. Komposisi mineral opak $(42 \%)$, piroksen $(37 \%)$, plagioklas $(15 \%)$, hornblenda (4\%), dan olivin (2\%). Di dalam sayatan tipis batuan ini menunjukkan struktur skoria, tekstur porfiritik, hipokristalin, berukuran halus hingga $1,78 \mathrm{~mm}$, bentuk kristal euhedral hingga anhedral, terdapat banyak ronggarongga halus (Gambar 12). Hasil analisis raman spectroscopy mengandung mineral labradorit $(69,35 \%)$, diopsid $(64,49 \%)$, augit $(54,28 \%)$, dan pollucit $(44,46 \%)$ (Gambar 13).

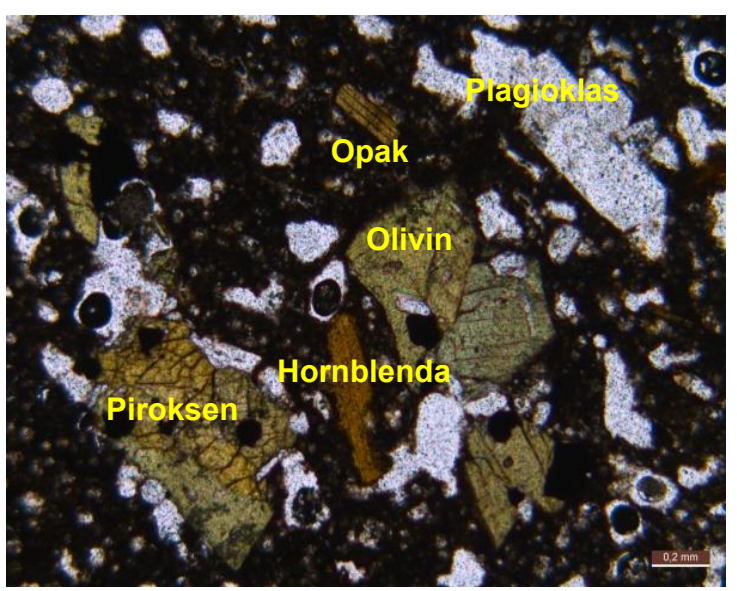

Gambar 12. Fotomikrograf sayatan tipis, berupa mineral opak dan piroksen
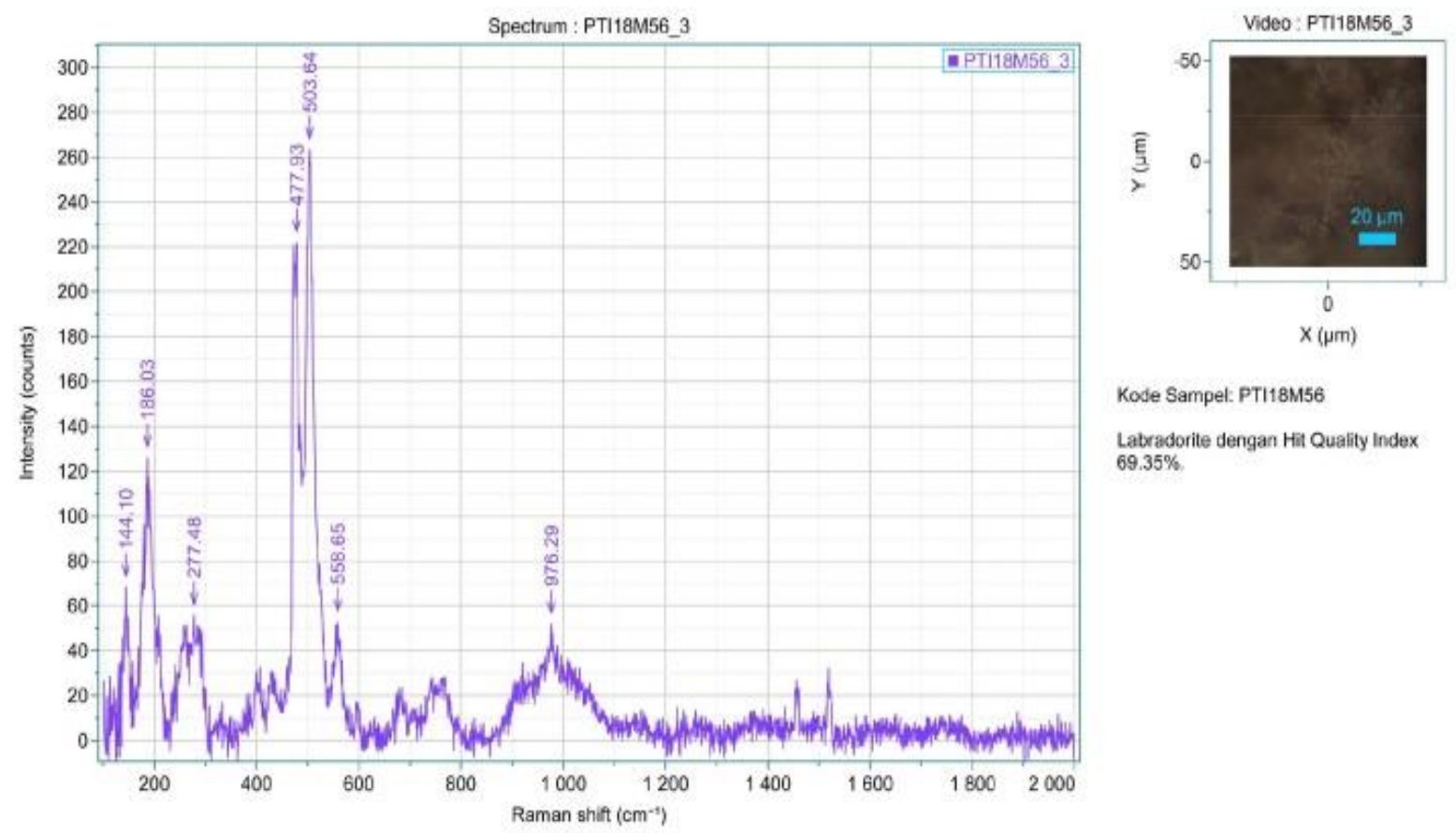

Kode Sampel: PTI18M56

Labradorite dengan Hit Quality Index $69.35 \%$

\begin{tabular}{|c|c|c|c|c|c|c|c|}
\hline Instrument & XploRA Plus & ACQ. time (3) & 2 & Accumulations & 7 & Laser (nm) & 532 \\
\hline Spectro (cm-') & & Hole $(\mu \mathrm{m})$ & 500 & Sit $(\mu \mathrm{m})$ & 200 & Grating & $2400 \mathrm{grimm}$ \\
\hline Filter & $100 \%$ & Objective & x50LWD & ICS porrection & Off & Range (cm-1) & \\
\hline
\end{tabular}

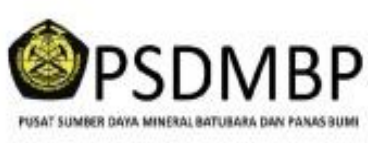

Gambar 13. Mineral labradorit hasil analisis raman spectroscopy 


\section{MAKALAH ILMIAH}

\section{Blok Medani}

Blok Medani memiliki luas sebaran sekitar $345,20 \mathrm{Ha}$ dengan berat jenis rata-rata 2,86, diperoleh sumber daya terukur 1.407.983.000 ton. Berdasarkan hasil analisis kimia major element terhadap 30 conto permukaan mempunyai kandungan $\mathrm{K}_{2} \mathrm{O}$ berkisar $0,23 \%$ s.d. $8,61 \%$. Kandungan $\mathrm{K}_{2} \mathrm{O}$ pada batuan lava berkisar antara $0,2 \%$ s.d. $8,61 \%$, dengan rata-rata $3,71 \%$, sedangkan pada batuan breksi berkisar antara $0,5 \%$ s.d. $6,25 \%$, dengan rata-rata $4,15 \%$. Hasil analisis petrografi di Blok Medani disusun oleh mineral leusit dan plagioklas, di dalam massa dasar yang disusun oleh mineral leusit, mikrolit plagioklas dan opak, dengan komposisi mineral leusit (55\%), plagioklas $(30 \%)$, opak $(5 \%)$, olivin $(5 \%)$, piroksen $(2 \%)$, biotit $(1 \%)$, muskovit $(1 \%)$, dan epidot $(1 \%)$. Di dalam sayatan tipis batuan ini menunjukkan tekstur porfiritik, hipokristalin, berukuran butir halus hingga 1,16 mm, bentuk kristal euhedral hingga anhedral (Gambar 14.). Hasil analisis raman spectroscopy mengandung mineral leusit $(73,07 \%)$, anorthoklas $(84,40 \%)$, andesin $(84,30 \%)$, labradorit $(71,64 \%)$, augit, dan sanidin (Gambar 15.).

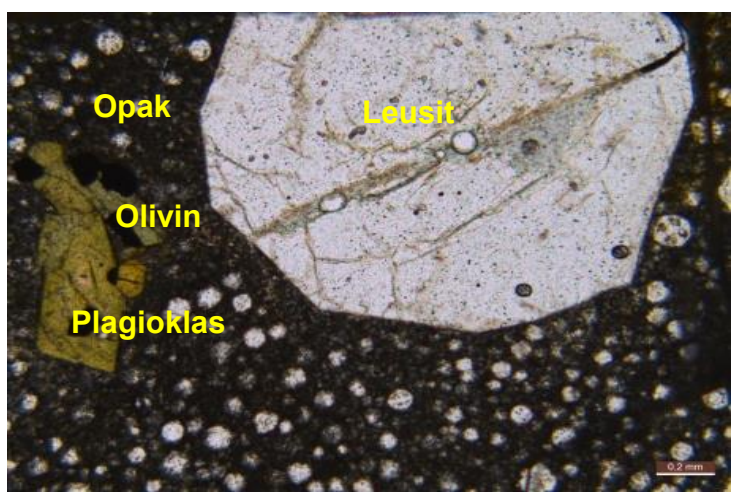

Gambar 14. Fotomikrograf sayatan tipis, berupa mineral leusit dan plagioklas

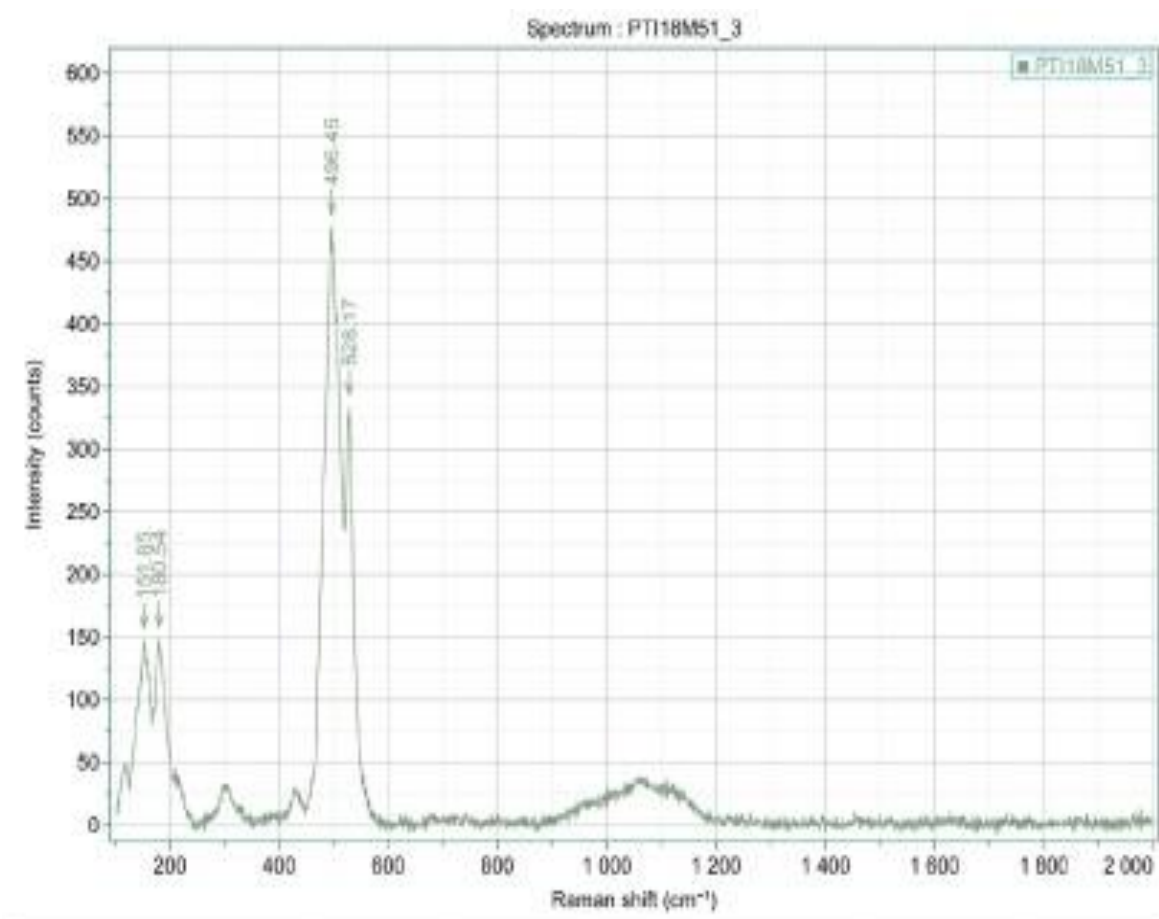

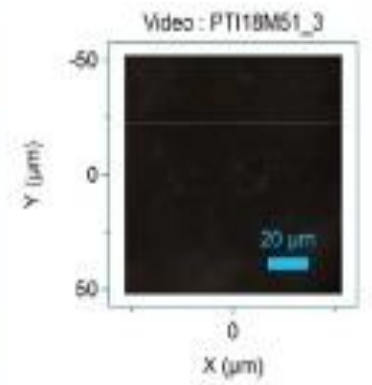

Kode Sampel: PTi1eM51A

Leuote dengan Hit Cuality Index $7307 \%$

\begin{tabular}{|c|c|c|c|c|c|c|c|}
\hline Irginument & XglareA Plas & Acq $3=0(8)$ & 2 & Accumistien & 7 & Lacet (cm) & $\mathrm{san}$ \\
\hline Spectre ion.') & & Hole $\{\mu \mathrm{n}\rangle$ & 500 & $\sin (\mu \mathrm{me})$ & 200 & Orativg & 2400 grimem \\
\hline Fher & $10 \% \%$ & Otjectivo & noouwo & KS consedion & on & Range (om,? & \\
\hline
\end{tabular}

Gambar 15. Mineral leusit hasil analisis raman spectroscopy 
Hasil analisis kimia major element terhadap conto permukaan di Kecamatan Cluwak sebanyak 113 conto ini, kemudian dilakukan pengolahan data untuk menentukan zonasi sebaran $\mathrm{K}_{2} \mathrm{O}$ pada ketiga blok. Blok Karangsari dibagi menjadi enam kisaran kadar $\mathrm{K}_{2} \mathrm{O}$, Blok Medani dibagi menjadi sembilan kisaran kadar $\mathrm{K}_{2} \mathrm{O}$, sedangkan Blok Sentul dibagi menjadi delapan kisaran kadar $\mathrm{K}_{2} \mathrm{O}$. Masing-masing kisaran kadar $\mathrm{K}_{2} \mathrm{O}$ di ketiga blok tersebut dapat diketahui luas sebarannya. Peta sebaran $\mathrm{K}_{2} \mathrm{O}$ di Kecamatan Cluwak, Kabupaten Pati, Provinsi Jawa Tengah dapat dilihat pada Gambar 16.

Berdasarkan hasil analisis XRF (X-Ray Fluorescent) yang dilakukan di Laboratorium Pusat Sumber Daya Mineral, Batubara dan Panas Bumi, Bandung, terhadap conto permukaan di ketiga blok sebaran dan conto bawah permukaan dari ketiga titik bor menghasilkan kandungan prosentase unsur kimia oksida seperti $\mathrm{SiO}_{2}, \mathrm{Al}_{2} \mathrm{O}_{3}, \mathrm{Fe}_{2} \mathrm{O}_{3}, \mathrm{CaO}, \mathrm{MgO}, \mathrm{Na}_{2} \mathrm{O}, \mathrm{K}_{2} \mathrm{O}$, $\mathrm{TiO}_{2}, \mathrm{MnO}_{3}, \mathrm{P}_{2} \mathrm{O}_{5}, \mathrm{SO}_{3}, \mathrm{HD}, \mathrm{H}_{2} \mathrm{O}$ dan BJ. Nilai prosentase unsur kimia oksida $\mathrm{SiO}_{2}$, $\mathrm{Na}_{2} \mathrm{O}$, dan $\mathrm{K}_{2} \mathrm{O}$ pada ketiga blok sebaran dan ketiga titik bor dimasukkan ke dalam diagram Total Alkali Silika (TAS) untuk mengetahui jenis batuannya. Blok Karangsari sebanyak 54 conto, Blok Sentul sebanyak 27 conto, Blok Medani sebanyak 30 conto, Titik Bor 1 (BH 01) sebanyak 21 conto, Titik Bor 2 (BH 02) sebanyak 19 conto, dan Titik Bor 3 (BH 03) sebanyak 26 conto. Hasil diagram TAS untuk batuan volkanik (Le Bas et al, 1986 dalam Andriane Machado et al, 2008) pada masing-masing blok dan titik bor, terlihat pada Gambar 17 sampai dengan Gambar 22.

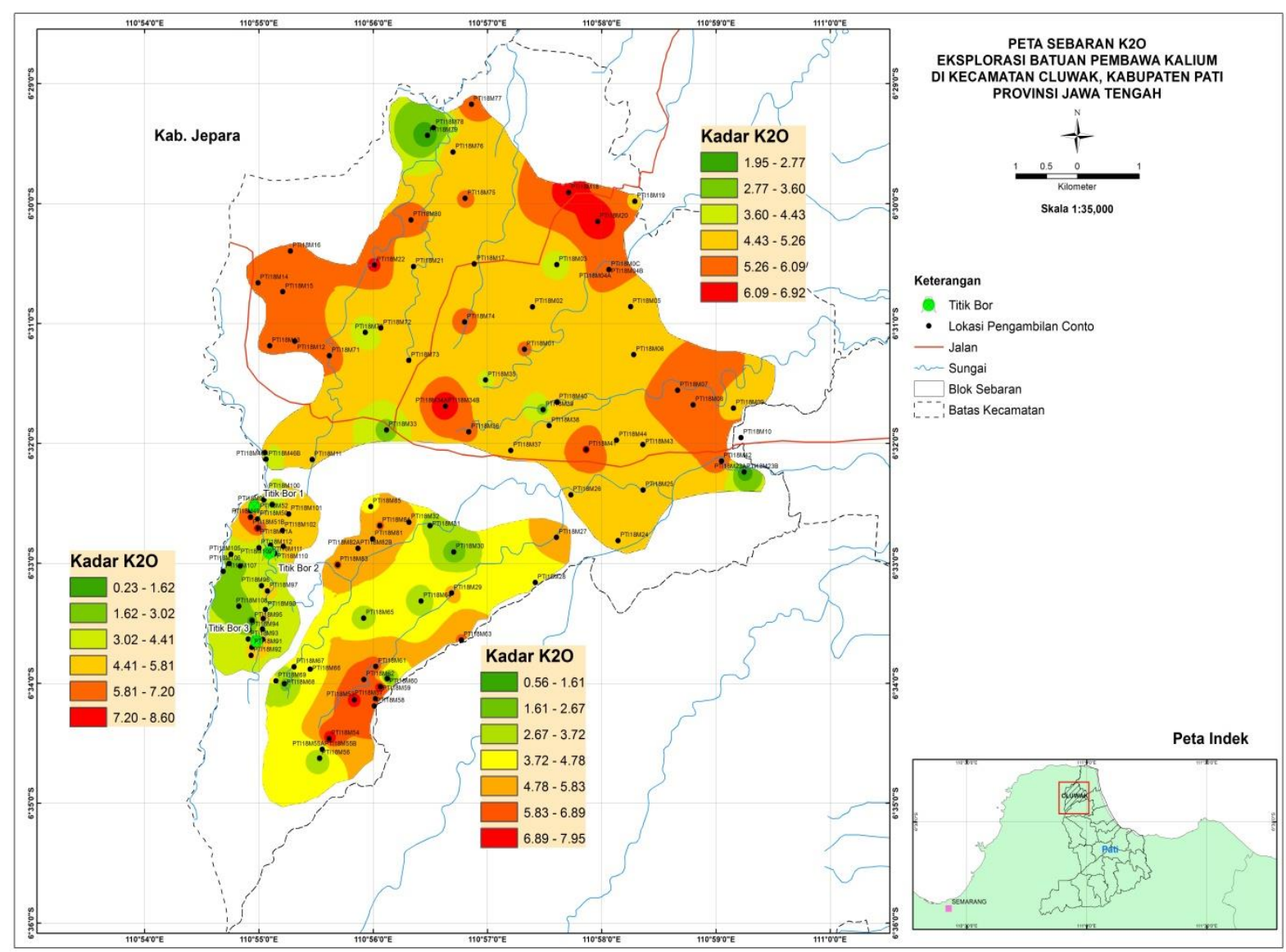

Gambar 16. Peta sebaran kandungan $\mathrm{K}_{2} \mathrm{O}$ di Kecamatan Cluwak, Pati, Jawa Tengah 


\section{MAKALAH ILMIAH}

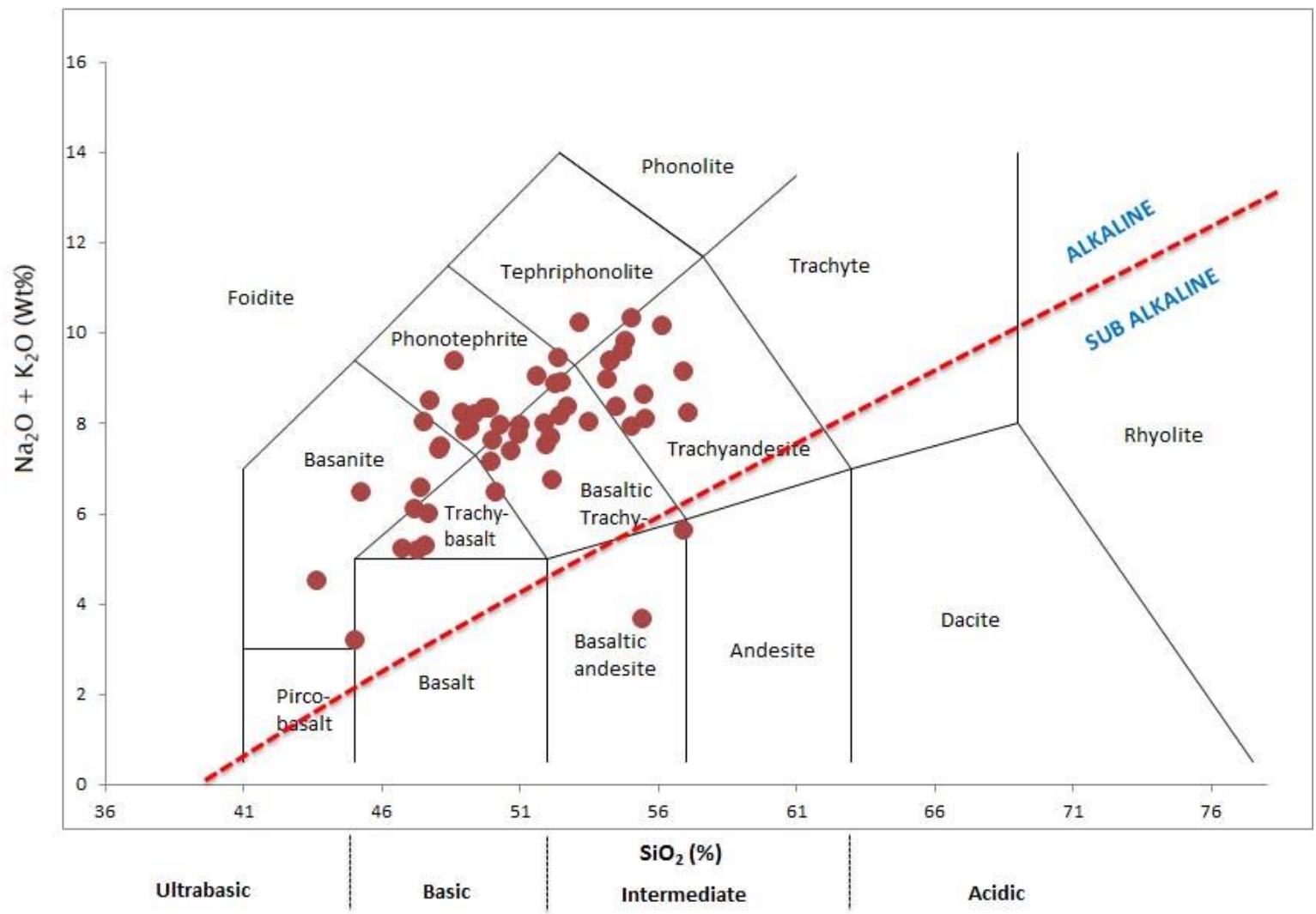

Gambar 17. Diagram TAS Blok Karangsari

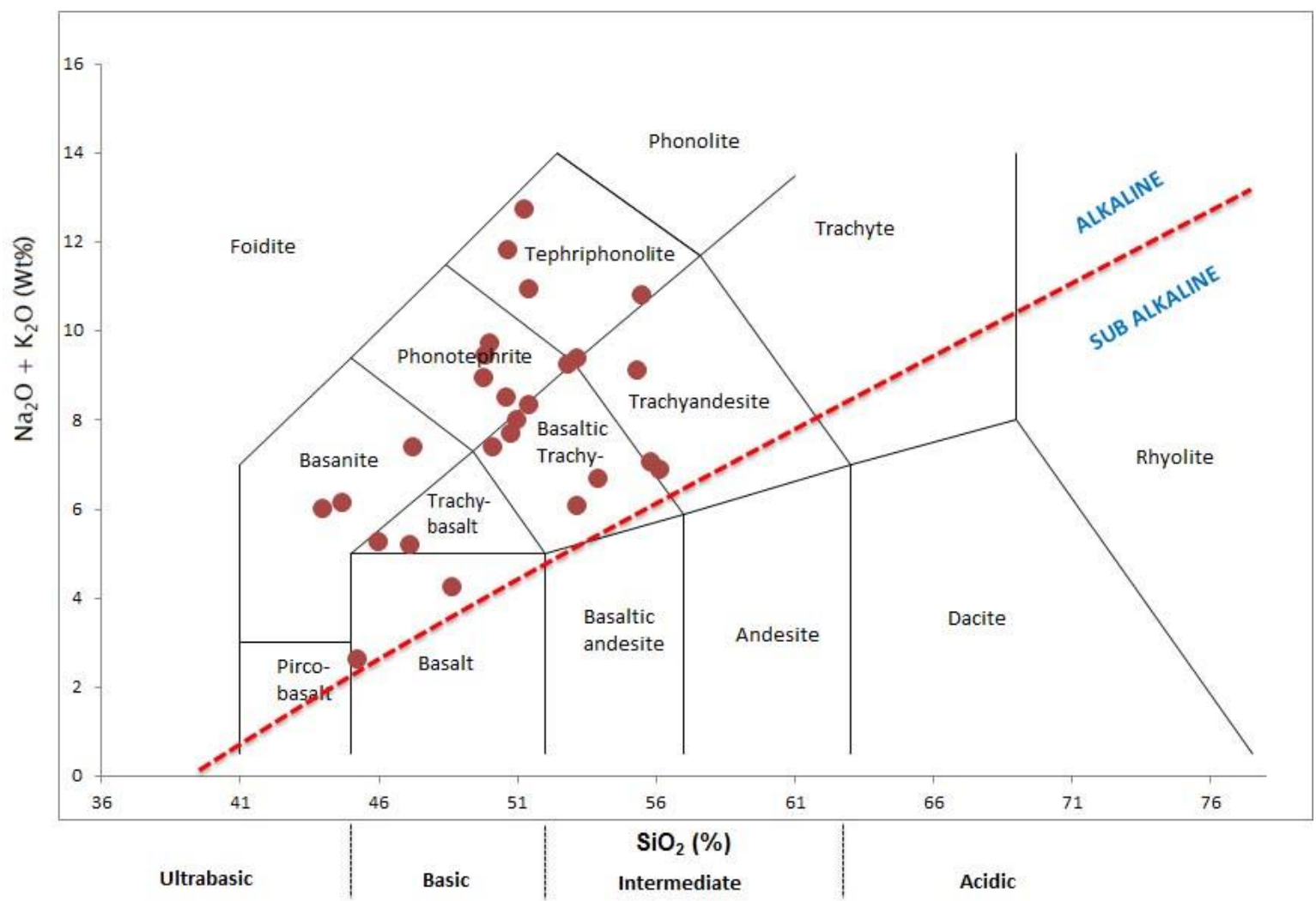

Gambar 18. Diagram TAS Blok Sentul 


\section{MAKALAH ILMIAH}

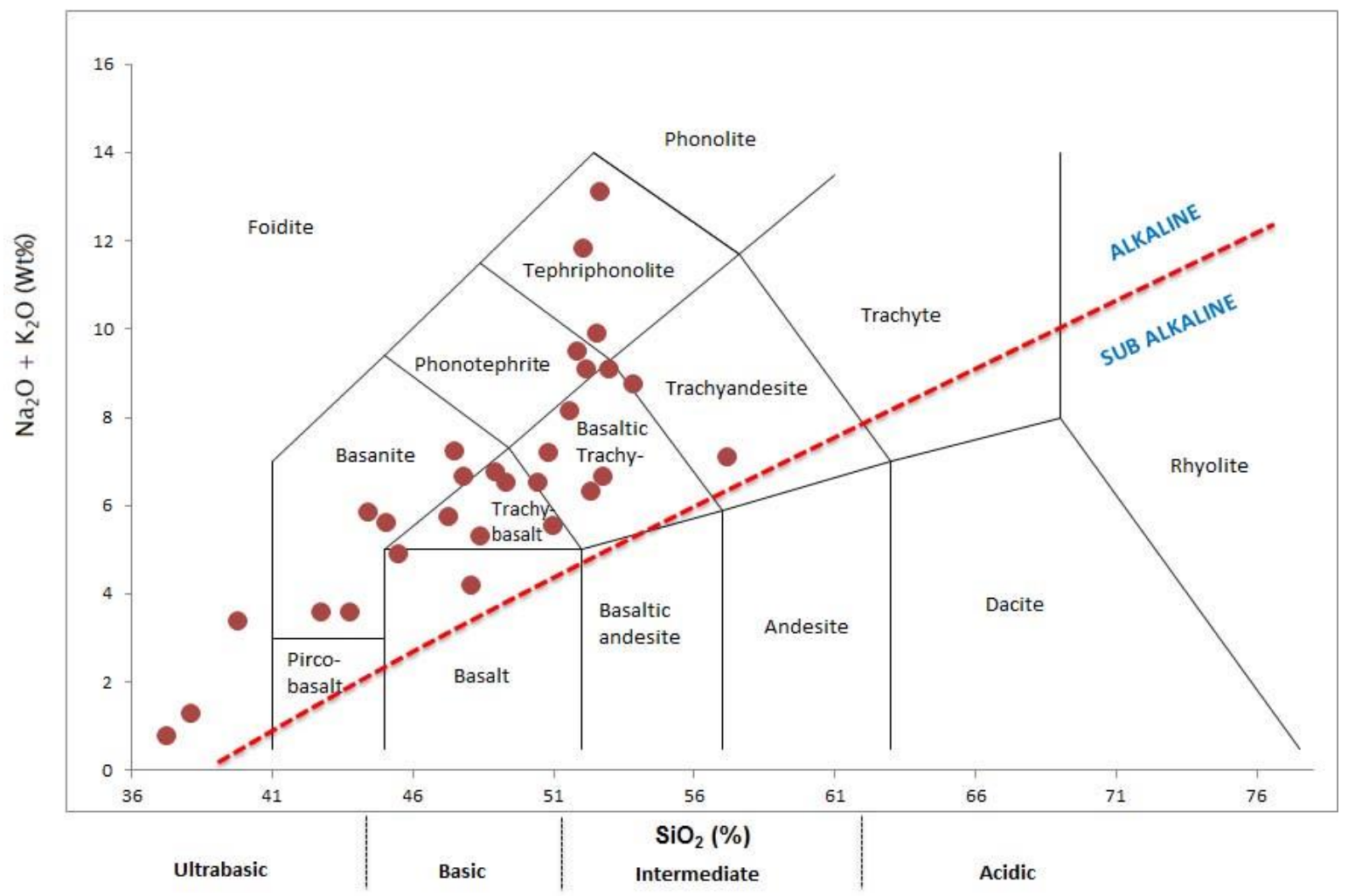

Gambar 19. Diagram TAS Blok Medani

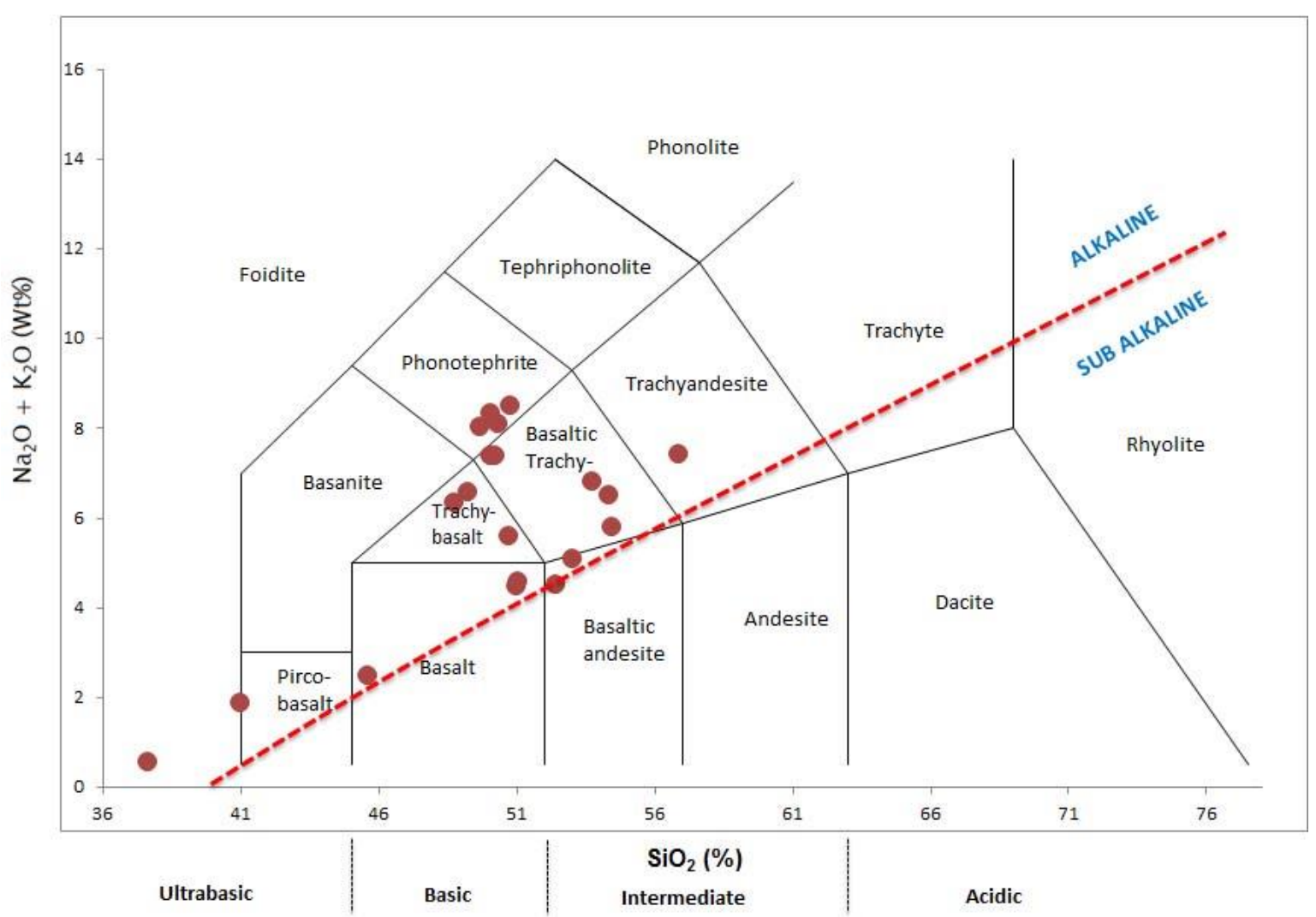

Gambar 20. Diagram TAS Titik Bor 01 


\section{MAKALAH ILMIAH}

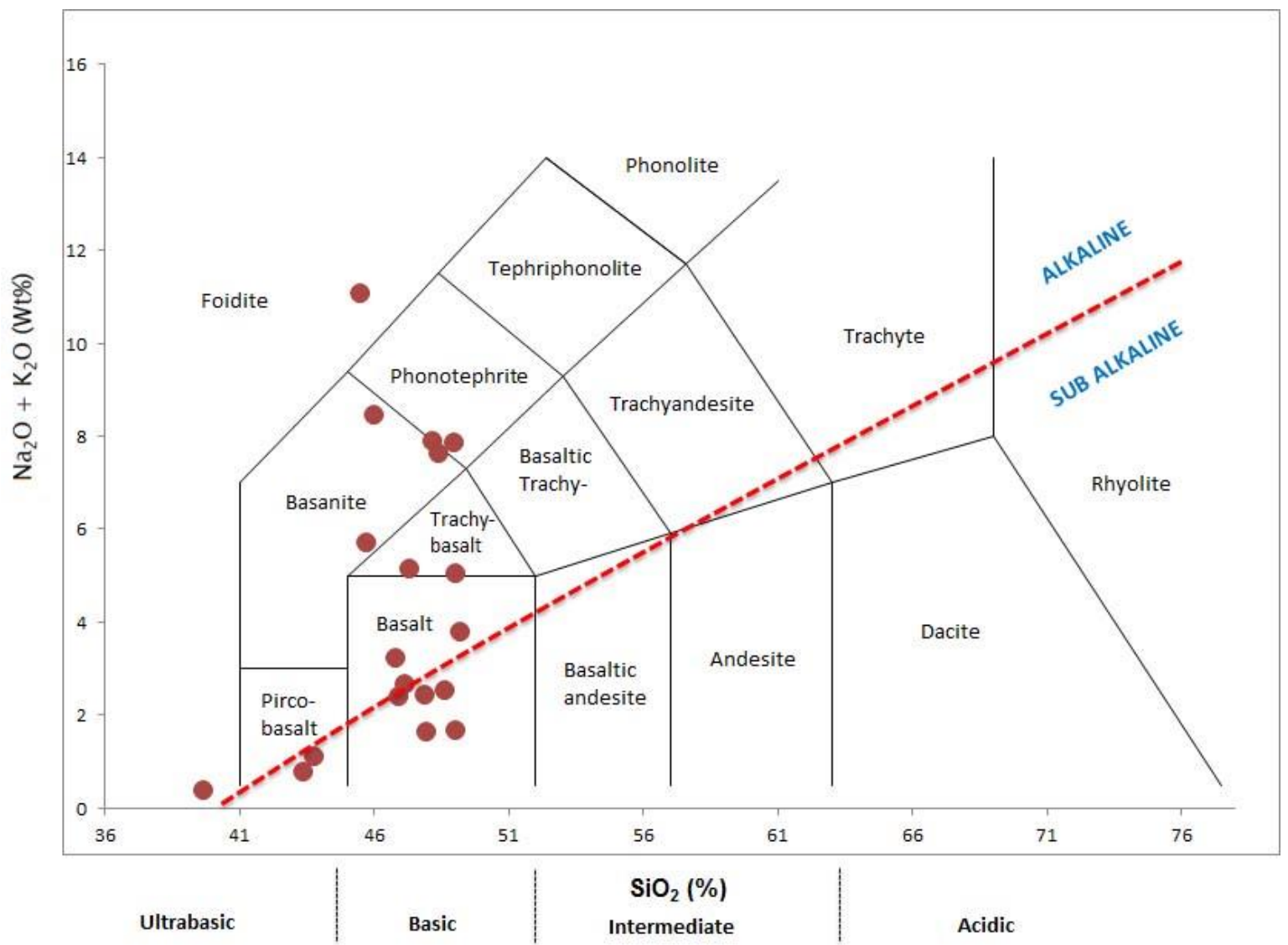

Gambar 21. Diagram TAS Titik Bor 02

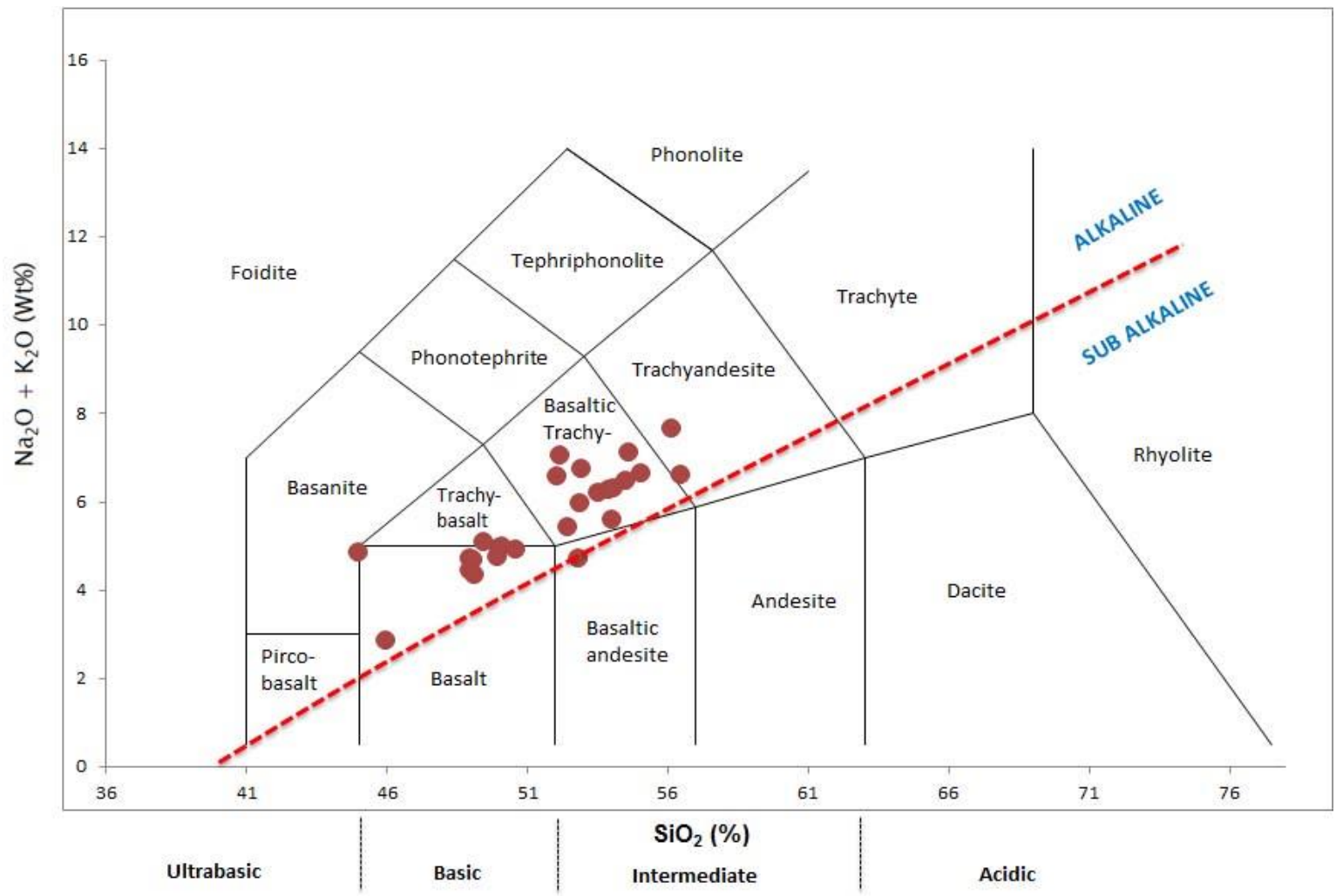

Gambar 22. Diagram TAS Titik Bor 03 
Berdasarkan keenam diagram di atas, pada umumnya jenis batuan di ketiga blok dan ketiga titik bor merupakan jenis batuan alkali, ada beberapa conto batuan di Titik Bor 02 yang masuk jenis batuan sub alkali pada batuan basal. Hal tersebut terdapat kesesuaian dengan hasil analisis petrografi yang menyatakan jenis batuan dengan komposisi mineral leusit (55\% s.d. $63 \%$ ), opak ( $5 \%$ s.d. $42 \%$ ), piroksen $(37 \%)$, dan plagioklas (15\% s.d. $30 \%)$. Demikian juga sesuai dengan hasil analisis raman spectroscopy yang menyatakan bahwa batuan mengandung mineral anorthoklas $(84,40 \%$ s.d. $90,82 \%)$, andesin $(84,30 \%)$, leusit $(72,23 \%$ s.d. $73,07 \%)$, labradorit $(69,35 \%$ s.d. $71,64 \%)$, diopsid $(64,49 \%)$, augit $(54,28 \%$ s.d. $62,19 \%)$, dan pollusit $(44,46 \%)$.

Selanjutnya, dari keseluruhan hasil analisis conto permukaan dan bawah permukaan sebanyak 177 conto di Kecamatan Cluwak, Pati, khususnya unsur oksida, prosentase unsur oksida $\mathrm{SiO}_{2}$ disebandingkan dengan unsur oksida $\mathrm{K}_{2} \mathrm{O}$ (Peccerillo \& Taylor, 2976 dalam Soviati dkk., 2017) dan unsur oksida $\mathrm{Na}_{2} \mathrm{O}$ disebandingkan dengan unsur oksida $\mathrm{K}_{2} \mathrm{O}$ (Middlemost, 1975 dalam Machado et al, 2008). Hasil kedua diagram tersebut seperti terlihat pada Gambar 23 dan Gambar 24.

Diagram $\mathrm{SiO}_{2}$ dan $\mathrm{K}_{2} \mathrm{O}$ pada umumnya menunjukkan jenis batuan seri alkalin yang mengandung silika rendah dan alkalin yang tinggi, terbagi menjadi absarokite dan shoshonite (Gambar 23.). Shoshonite merupakan jenis batuan beku, varietas kalium kaya trachyandesite basaltik, terdiri dari olivin, augit dan fenokris plagioklas dalam suatu masa dasar dengan plagioklas dan sanidin kalsik dan beberapa gelas vulkanik berwarna gelap. Shoshonite memberikan namanya pada seri shoshonite dan memberikan nilai menjadi absarokite dengan hilangnya fenokris plagioklas dan menjadi bannakite dengan peningkatan sanidin. Demikian juga hasil pengeplotan diagram $\mathrm{Na}_{2} \mathrm{O}$ dan $\mathrm{K}_{2} \mathrm{O}$, pada umumnya termasuk pada golongan Seri Kalium (Potassic Series) sampai Seri Kalium Tinggi (High-K-Series) seperti terlihat pada Gambar 24.

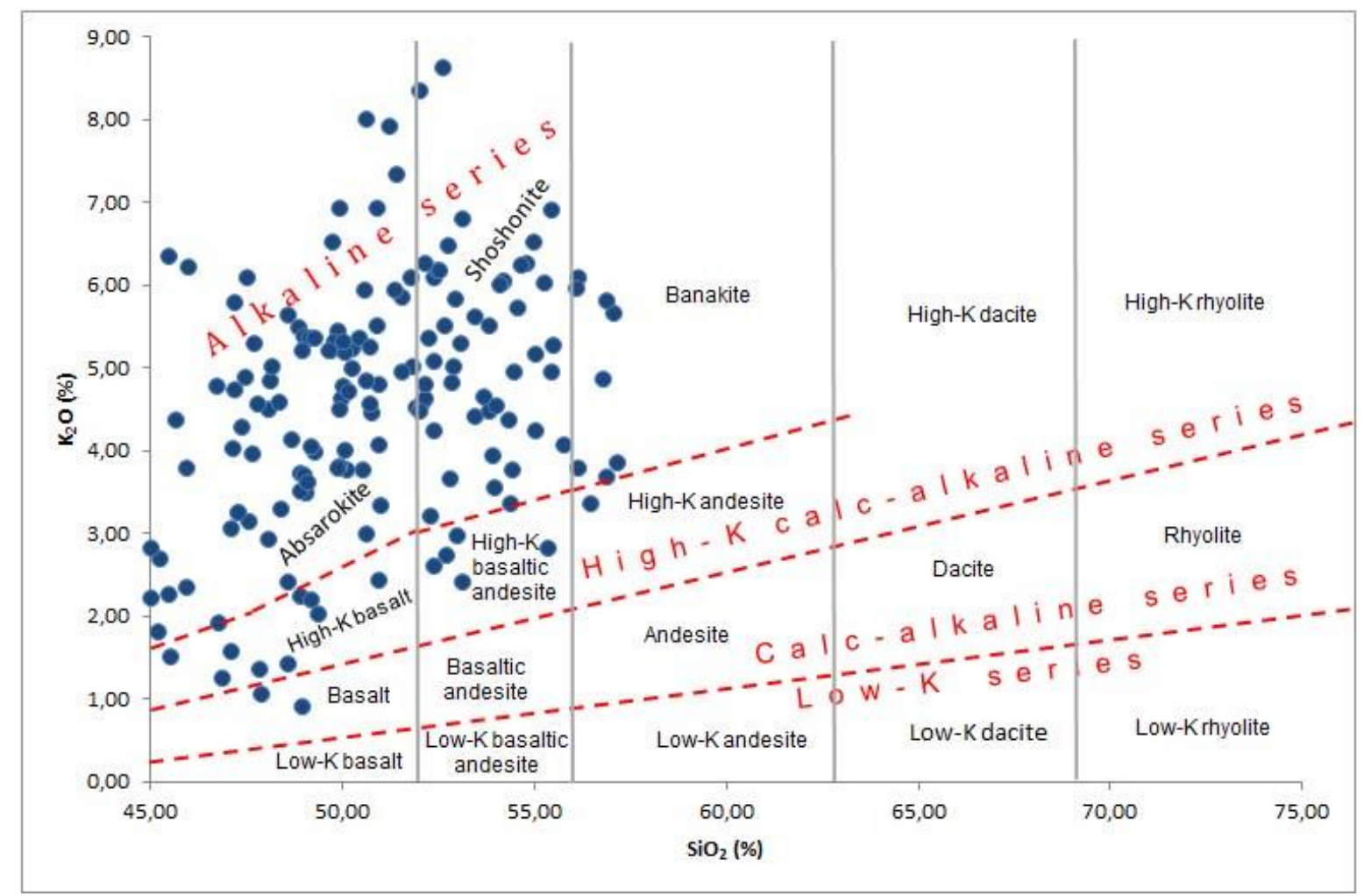

Gambar 23. Diagram $\mathrm{SiO}_{2}$ vs $\mathrm{K}_{2} \mathrm{O}$ 


\section{MAKALAH ILMIAH}



Gambar 24. Diagram $\mathrm{Na}_{2} \mathrm{O}$ vs $\mathrm{K}_{2} \mathrm{O}$

Mineral-mineral yang umumnya dianggap sebagai sumber asli dari kalium, diantaranya adalah leusit $\left[\mathrm{K}\left(\mathrm{AlSi}_{2} \mathrm{O}_{6}\right)\right]$, biotit [K(Mg, $\left.\mathrm{Fe}) 3 \mathrm{AlSi}_{3} \mathrm{O}_{10}\right]$, kalium felspar ortoklas dan mikrolin $\left(\mathrm{KAISi}_{3} \mathrm{O}_{8}\right.$ ) (Kusdarto, dkk., 2008). Penambahan mineral leusit menunjukkan hasil yang relatif sama dengan standar NPK (Relative Agronomic Effectiveness/RAE 123\%) (Hartati, et al, 2018).

Pemanfatan batuan pembawa kalium di Kecamatan Cluwak, Kabupaten Pati sebagai bahan baku pupuk alami telah dilakukan analisis laboratorium dengan parameter tanah $\mathrm{K}_{2} \mathrm{O}, \mathrm{HCl} 25 \%$ dan Asam sitrat $2 \%$ Bray sebanyak 110 conto di
Laboratorium Tanah, Tanaman, Pupuk, Air Badan Penelitian dan Pengembangan Pertanian, Bogor. Hasil analisis tersebut di plot dalam kurva kriteria penilaian hasil analisis tanah seperti terlihat pada Tabel 2.

Untuk parameter tanah $\mathrm{K}_{2} \mathrm{O}, \mathrm{HCl} 25 \%$ menghasilkan lima kategori dengan prosentase $9,1 \%$ termasuk kriteria sangat rendah, $13,6 \%$ rendah, $8,2 \%$ sedang, $16,4 \%$ tinggi dan $51,8 \%$ sangat tinggi (> $60)$. Sedangkan dengan parameter tanah Asam sitrat $2 \%$ Bray didapatkan hasil $100 \%$ termasuk kriteria sangat tinggi (> $15)$.

Tabel 2. Kriteria Penilaian Hasil Analisis Tanah

\begin{tabular}{lccccc}
\hline \multicolumn{1}{c}{ Parameter Tanah } & $\begin{array}{c}\text { Sangat } \\
\text { Rendah }\end{array}$ & Rendah & Sedang & Tinggi & $\begin{array}{c}\text { Sangat } \\
\text { Tinggi }\end{array}$ \\
\hline $\mathrm{K}_{2} \mathrm{O}, \mathrm{HCl} 25 \%(\mathrm{mg} / 100 \mathrm{~g})$ & $<10$ & $10-20$ & $21-40$ & $41-60$ & $>60$ \\
\hline $\mathrm{P}_{2} \mathrm{O}_{5}$ Bray $(\mathrm{ppm})$ & $<4$ & $5-7$ & $8-10$ & $11-15$ & $>15$
\end{tabular}

Sumber : Badan Penelitian dan Pengembangan Pertanian, Kementerian Pertanian 2012 Catatan : $\mathrm{P}_{2} \mathrm{O}_{5}$ Bray setara dengan Asam sitrat $2 \%$ 


\section{UCAPAN TERIMA KASIH}

Penulis mengucapkan terima kasih kepada Ir. Martua Raja P., Ir. Ganjar Labaik, John Mauritz F. P., ST., dan Nining Widaningsih, S.Si. dari Bidang Mineral, Pusat Sumber Daya Mineral, Batubara dan Panas Bumi yang telah membantu dan memberikan masukannya sehingga makalah ini dapat diselesaikan dengan lancar. Kepada Dewan Redaksi, penulis mengucapkan terima kasih atas masukan dan penyempurnaan makalah ini.

\section{DAFTAR PUSTAKA}

Anonim, 2018, Analisis Ringkas Cepat; Alternatif Kebijakan Subsidi Pupuk Dalam Rangka Meningkatkan Produksi Pangan dan Pemerataan Kesejahteraan Petani, Pusat Kajian Anggaran Badan Keahlian, Dewan Perwakilan Rakyat Republik Indonesia.

Hendrawan, D. S., Daryanto, A., Sanim, B., dan Siregar, H., 2011, Analisis Kebijakan Subsidi Pupuk: Penentuan Pola Subsidi dan Sistem Distribusi Pupuk di Indonesia, Jurnal Manajemen Agribisnis Volume 8 Nomor 2, Oktober 2011.

Hartati, S., Minardi, S., Hartatik, W., and Haniati, I., L., 2018, The Effects of Inorganic Fertilizer and Mineral Leucite Residues on K uptake and Maize Yields (Zie Mays L.) in Oxisols, Journal of Soil Science and Agroclimatology, 15 (2), 2018, 115122.

Kadar, D., dan Sudijono, 1993, Peta Geologi Lembar Rembang, Jawa sekala 1 : 250.000, Pusat Penelitian dan Pengembangan Geologi, Bandung.

Khoirunisa, 2017, Pengaruh Pemberian Mineral Leusit dan Mikroba Pelarut Kalium Terhadap Ketersediaan dan Serapan Hara Kalium Tanaman Kacang Tanah (Arachis hypogaea) Pada Tanah Inceptisol, Skripsi, Program Studi Agrotektologi, Fakultas Pertanian, Universitas Jember.
Kusdarto, Labaik, G., Karangan, C., dan Sayekti, B., 2008, Eksplorasi Umum Agromineral di Kabupaten Situbondo, Provinsi Jawa Timur. Pusat Sumber Daya Geologi, Badan Geologi, Bandung.

Lasindrang, R. Z. Y., dan Fauzi, A., 2018, Hubungan Distribusi Terhadap Penjualan (Studi pada distribusi pupuk NPK non subsidi area pemasaran Kalimantan di PT Pupuk Kalimantan Timur), Jurnal Administrasi Bisnis (JAB) Volume 54 No. 1, Januari 2018.

Machado, A., Azevedo, J. M. M., Almeida, D. P. M., and Chemale, F., 2008, Geochemistry of Volcanic Rocks from Faial Island (Azores). GeoticSociedade Geologica de Portugal, Volume 5, No. 1 : 2008, 1 - 14.

Muksin, I., Kusdarto, Sayekti, B., dan Zulfikar, 2011, Penelitian Agromineral di Kabupaten Jepara, Provinsi Jawa Tengah, Pusat Sumber Daya Geologi, Prosiding Hasil Kegiatan Lapangan, Nomor 6 ISSN : 0261-0811.

Muksin, I., Raja, M., dan Karangan, C., 2015, Eksplorasi Umum Agromineral di Kecamatan Donorojo Kabupaten Jepara, Provinsi Jawa Tengah, Pusat Sumber Daya Geologi, Prosiding Hasil Kegiatan Lapangan, Nomor 10 ISSN : 0261-0811.

Muksin, I., dan Karangan, C., 2016, Prospeksi Batuan Pembawa Kalium Kabupaten Pati, Provinsi Jawa Tengah, Pusat Sumber Daya Mineral Batubara dan Panas Bumi, Prosiding Hasil Kegiatan Lapangan, Nomor 11 ISSN : 0261-0811.

Muksin, I., Raja, M., dan Mauritz, J., 2017, Prospeksi Batuan Pembawa Kalium Kabupaten Kudus, Provinsi Jawa Tengah, Pusat Sumber Daya Mineral Batubara dan Panas Bumi, Prosiding Hasil Kegiatan Lapangan, Nomor 12 ISSN : 0261-0811.

Muksin, I., Raja, M., dan Mauritz, J., 2018, Eksplorasi Batuan Pembawa Kalium Dengan Cara Pengeboran di Kecamatan Cluwak, Kabupaten Pati, Provinsi Jawa Tengah. 


\section{MAKALAH ILMIAH}

Soviati, A., E., Syafri, I., dan Patonah, A., 2017, Petrogenesis Batuan Andesit Bukit Cangkring, Daerah Jelekong, Kecamatan Baleendah, Kabupaten Bandung, Jawa Barat. Padjadjaran Geoscience Journal Vol. 1, No. 2, Oktober 2017, 98 - 105.

Suryana, A., Agustian, A., dan Yofa, R. D., 2016, Alternatif Kebijakan Penyaluran Subsidi Pupuk Bagi Petani Pangan, Analisis Kebijakan Pertanian, Volume 14 No. 1, Juni $2016: 35-54$.
Suwarti, T. dan Wikarno, R., 1992., Peta Geologi Lembar Kudus, Jawa skala 1 : 250.000, Pusat Penelitian dan Pengembangan Geologi, Bandung.

Syakir, M., dan Gusmaini, 2012, Pengaruh Penggunaan Sumber Pupuk Kalium Terhadap Produksi dan Mutu Minyak Tanaman Nilam, Jurnal Littri Volume 18 No 2, Juni $2012: 60-65$.

\begin{tabular}{|ll|}
\hline Diterima & $: 28$ Mei 2018 \\
Direvisi & $: 6$ Februari 2019 \\
Disetujui & $: 27$ Maret 2019 \\
\hline
\end{tabular}

